\title{
Sphingobacterium gen. nov., Sphingobacterium spiritivorum comb. nov., Sphingobacterium multivorum comb. nov., Sphingobacterium mizutae sp. nov., and Flavobacterium indologenes sp. nov.: Glucose-Nonfermenting Gram-Negative Rods in CDC Groups IIK-2 and IIb
}

\author{
EIKO YABUUCHI, ${ }^{1 *}$ TAKICHI KANEKO,${ }^{2}$ IKUYA YANO,${ }^{3} \mathrm{C}$. WAYNE MOSS,${ }^{4}$ AND NORIKO \\ MIYOSHI ${ }^{5} \dagger$
}

Department of Microbiology, Gifu University School of Medicine, Tsukasa-machi 40, Gifu 500, Japan ${ }^{1}$; Institute for Chemical and Physical Research, Wako, Saitama 351, Japan ${ }^{2}$; Department of Bacteriology, Niigata University School of Medicine, Asahimachi-dori, Niigata 951, Japan ${ }^{3}$; Centers for Disease Control, Atlanta, Georgia 303334; and Osaka Perinatal Medical Center and Research Institute, Izumi, Osaka 590-02, Japan $^{5}$

A new genus, Sphingobacterium, two new combinations, Sphingobacterium spiritivorum (Holmes, Owen, and Hollis) and Sphingobacterium multivorum (Holmes, Owen, and Weaver), and two new species, Sphingobacterium mizutae and Flavobacterium indologenes, are described. The genus Sphingobacterium is characterized and distinguished from the genus Flavobacterium by the presence in its strains of high concentrations of sphingophospholipids as cellular lipid components. S. spiritivorum is designated the type species of the genus Sphingobacterium. S. mizutae ATCC 33299 (= GIFU 1203) and $F$. indologenes ATCC $29893(=$ CDC $3716=$ GIFU $1347=$ NCTC $10796=$ RH 542) are designated the type strains of the two new species. Emended descriptions of the type strains of $S$. spiritivorum and $S$. multivorum are presented.

During the course of a cellular lipid analysis of glucose-nonfermenting gram-negative rods, Yano et al. (I. Yano et al., Proc. Jpn. Conf. Biochem. Lipids 19:19-22, 1977) found that the cells of six strains of Pseudomonas-like group IIk-2 (28) contained unique sphingophospholipids. The major ceramide species of these compounds was identified as $N$-2-hydroxy-13methyltetradecanoly-15(?)-methylhexadecasphinganine (36). Yabuuchi et al. (34) compared the phenotypic characteristics, cellular lipid compositions, and guanine-plus-cytosine $(\mathrm{G}+\mathrm{C})$ contents of the deoxyribonucleic acids (DNAs) of 12 strains of group IIK-2, 41 strains of five species of Flavobacterium, and the type strain of Cytophaga johnsonae. On the bases of these results and the presence of the unique sphingophospholipids, Sphingobacterium gen. nov. and Sphingobacterium versatilis sp. nov. were proposed for group IIK-2 strains, and the species was tentatively divided into three biovars; strain ATCC 33300 (= KM 2138) was designated the type strain of $S$. versatilis. Detailed studies of the three biovars of $S$. versatilis led to recognition of each biovar as a separate species; these

$\dagger$ Present address: Department of Microbiology, Gifu University School of Medicine, Tsukasa-machi 40, Gifu 500, Japan. species were $S$. versatilis sp. nov., $S$. phingobacterium multivorum (Holmes, Owen, and Weaver) comb. nov. $(11,30)$, and Sphingobacterium mizutae (30).

Before valid publication of these new names, Holmes et al. (10) proposed the new name Flavobacterium spiritivorum for a group of organisms which correspond to $S$. versatilis. In this paper we propose, in accordance with the Bacteriological code (1975 Revision), Sphingobacterium gen. nov., Sphingobacterium spiritivorum (Holmes, Owen, and Hollis 1982) comb. nov. (type species of the genus), Sphingobacterium multivorum (Holmes, Owen, and Weaver 1981) comb. nov., and Sphingobacterium mizutae sp. nov.

Because of its frequent isolation from human specimens and from hospital environments and its deep orange pigment, a nonmotile, gramnegative, rod-shaped bacterium is well known among clinical bacteriologists as King group IIb (27). King group IIa is Flavobacterium meningosepticum (14). Group IIb has not been assigned nomenclatural status, despite numerous descriptions of its phenotypic and genotypic characteristics $(19,21-23,25,28,32,35)$. We compared strains of group IIb with strains of four other Flavobacterium species including Flavobacter- 


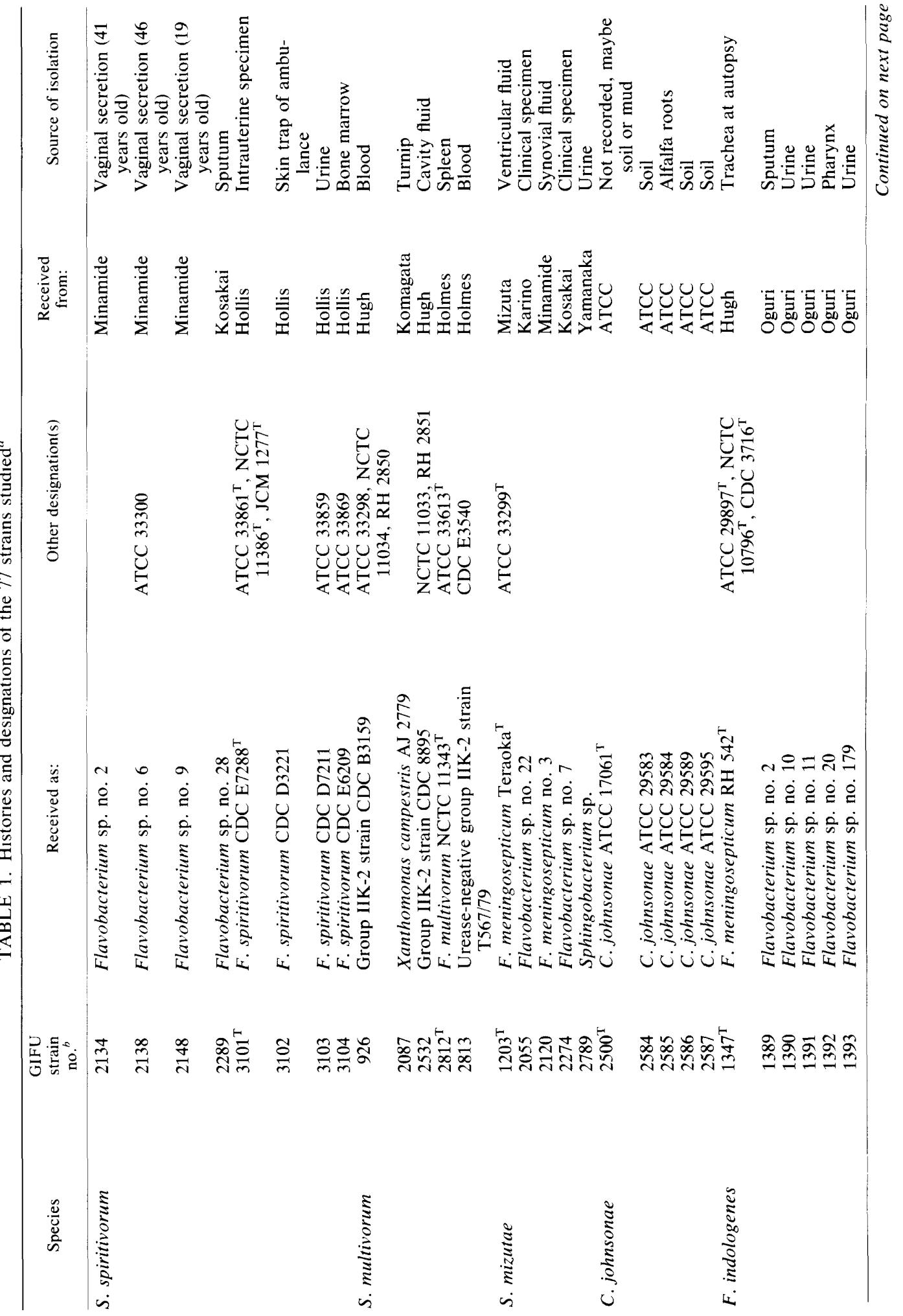




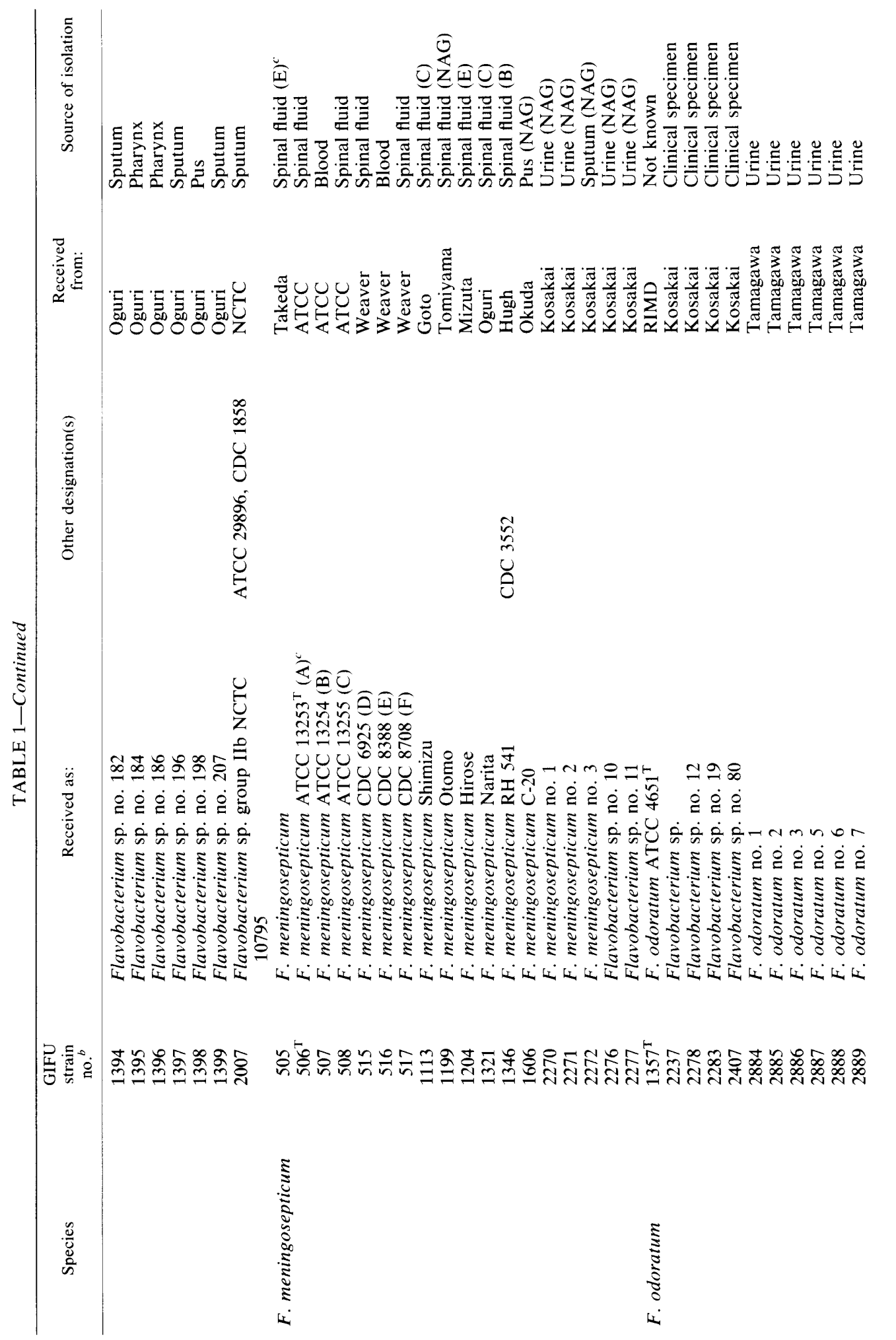




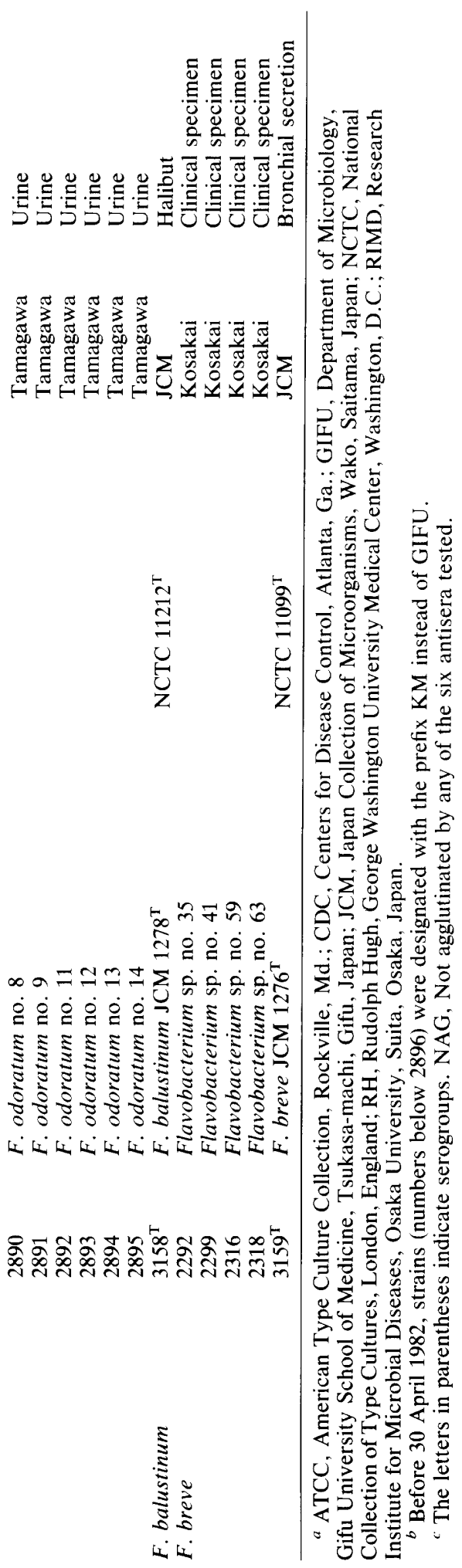

ium balustinum Harrison 1929 (8), and found that the group IIb strains constitute a separate species, for which we propose the name Flavobacterium indologenes $\mathrm{sp}$. nov.

The type strains of $S$. mizutae and $F$. indologenes are designated.

\section{MATERIALS AND METHODS}

Bacterial strains. The 77 strains of nine species examined in this study are listed in Table 1 . All strains except the following were isolated from clinical materials: all of the $C$. johnsonae strains, Flavobacterium odoratum GIFU $1357^{\mathrm{T}}$ (type strain), F. balustinum GIFU $3158^{\mathrm{T}}, S$. spiritivorum GIFU 3102 , and $S$. multivorum GIFU 2087. The reference strains used for DNA homology studies included Cytophaga lytica GIFU 2490, "Cytophaga marinoflava" GIFU 2502, Cytophaga sp. strain GIFU 2506, Legionella pneumophila GIFU $2522^{\mathrm{T}}\left(=\right.$ ATCC $\left.33152^{\mathrm{T}}\right)$, and Bacillus cereus ATCC $14597^{\mathrm{T}}$.

Determination of phenotypic characters. Cultures for all tests were incubated aerobically at $30^{\circ} \mathrm{C}$ unless stated otherwise. To observe spreading growth, semisolid motility medium (12) in a petri dish was inoculated at the center, and the culture was incubated at room temperature. The cellular arrangement at the edge of the spreading growth of a $0.5 \%$ agar medium culture on a glass microscope slide was determined by phasecontrast microscopy. Cell size was determined from phase-contrast micrographs.

Indole production was determined in $1 \%$ tryptone broth supplemented with $0.5 \%$ L-tryptophan (29). After $20 \mathrm{~h}$ of incubation, indole was detected by a distinct red color after Kovacs reagent was added. Filter paper impregnated with a $5.5 \%$ aqueous solution of lead acetate was air dried, cut into strips ( 5 by $50 \mathrm{~mm}$ ), and autoclaved in a glass petri dish. A lead acetate strip was suspended over a Kligler iron agar (Nissui, Tokyo, Japan) slant immediately after inoculation and then observed daily for 5 days for development of a dark brown color at the lower end. Oxidative acid production from carbohydrates (concentration, $1 \%$ ) or from $3 \%$ ethanol was determined in oxidation-fermentation basal medium (catalog no. 0688; Difco Laboratories, Detroit, Mich.). Skim acetate agar was prepared by the method of Christensen (6). The surface of a Mueller-Hinton agar plate was flooded with Gram iodine solution. A clear halo surrounding a culture indicated starch hydrolysis. Acylamidase activity was determined on slants of acetamide medium (Eiken, Tokyo, Japan) which contained (per liter) $0.5 \mathrm{~g}$ of yeast extract, $0.2 \mathrm{~g}$ of glucose, $5.0 \mathrm{~g}$ of $\mathrm{NaCl}, 1.0 \mathrm{~g}$ of $\mathrm{KH}_{2} \mathrm{PO}_{4}, 3.0 \mathrm{~g}$ of acetamide, $0.03 \mathrm{~g}$ of phenol red, and $15 \mathrm{~g}$ of agar; the $\mathrm{pH}$ of this medium was 6.3. Deoxyribonuclease (DNase) activity was determined on slants of DNase medium (Eiken), which contained (per liter) $15.0 \mathrm{~g}$ of casein peptone, $5.0 \mathrm{~g}$ of soy peptone, $5.0 \mathrm{~g}$ of $\mathrm{NaCl}, 2.0 \mathrm{~g}$ of DNA, $0.1 \mathrm{~g}$ of toluidine blue, and $15.0 \mathrm{~g}$ of agar; the $\mathrm{pH}$ of this medium was 7.3. One loopful of a 20-h broth culture was streaked onto each slant, and the preparation was incubated with the screw cap loosened. After 24 to $48 \mathrm{~h}$ of incubation, the development of a red color indicated acylamidase activity, and a purple color indicated DNase activity. The egg yolk reaction was recorded as positive if a clear zone which gradually became turbid to form a grayish white halo 


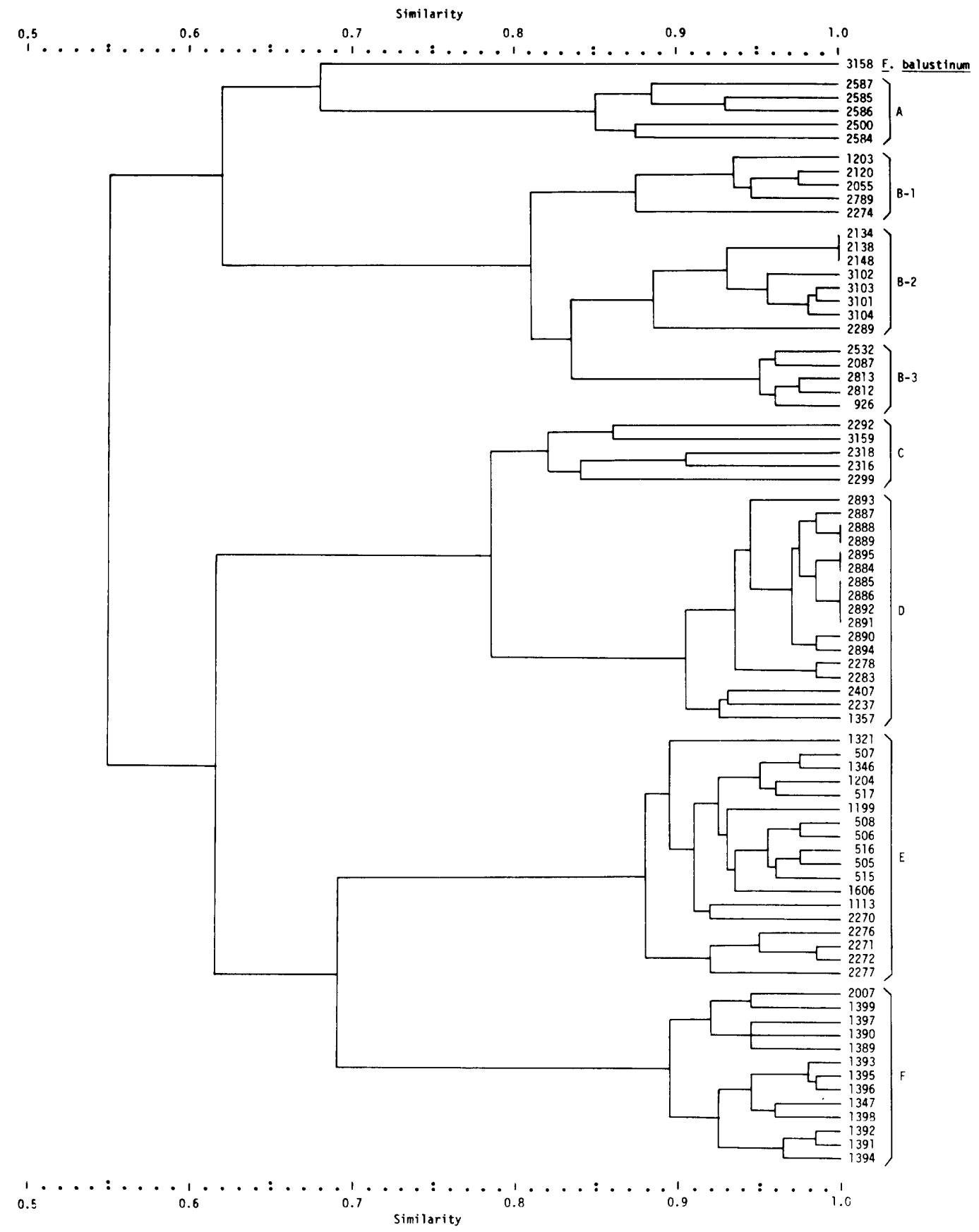

FIG. 1. Dendrogram prepared by simple matching and average-linkage methods for 73 effective data, using 107 phenotypic characters of 77 strains of nine species. F. balustinum GIFU $3158^{\mathrm{T}}$ is at the top of the dendrogram. Cluster A corresponded to $C$. johnsonae. Cluster B was divided into the following three subclusters: S. mizutae (subcluster B-1), S. spiritivorum (subcluster B-2), and S. multivorum (subcluster B-3). Cluster $\mathrm{C}$ corresponded to Flavobacterium breve; cluster D corresponded to $F$. odoratum; cluster E corresponded to $F$. meningosepticum; and cluster $F$ corresponded to $F$. indologenes. 


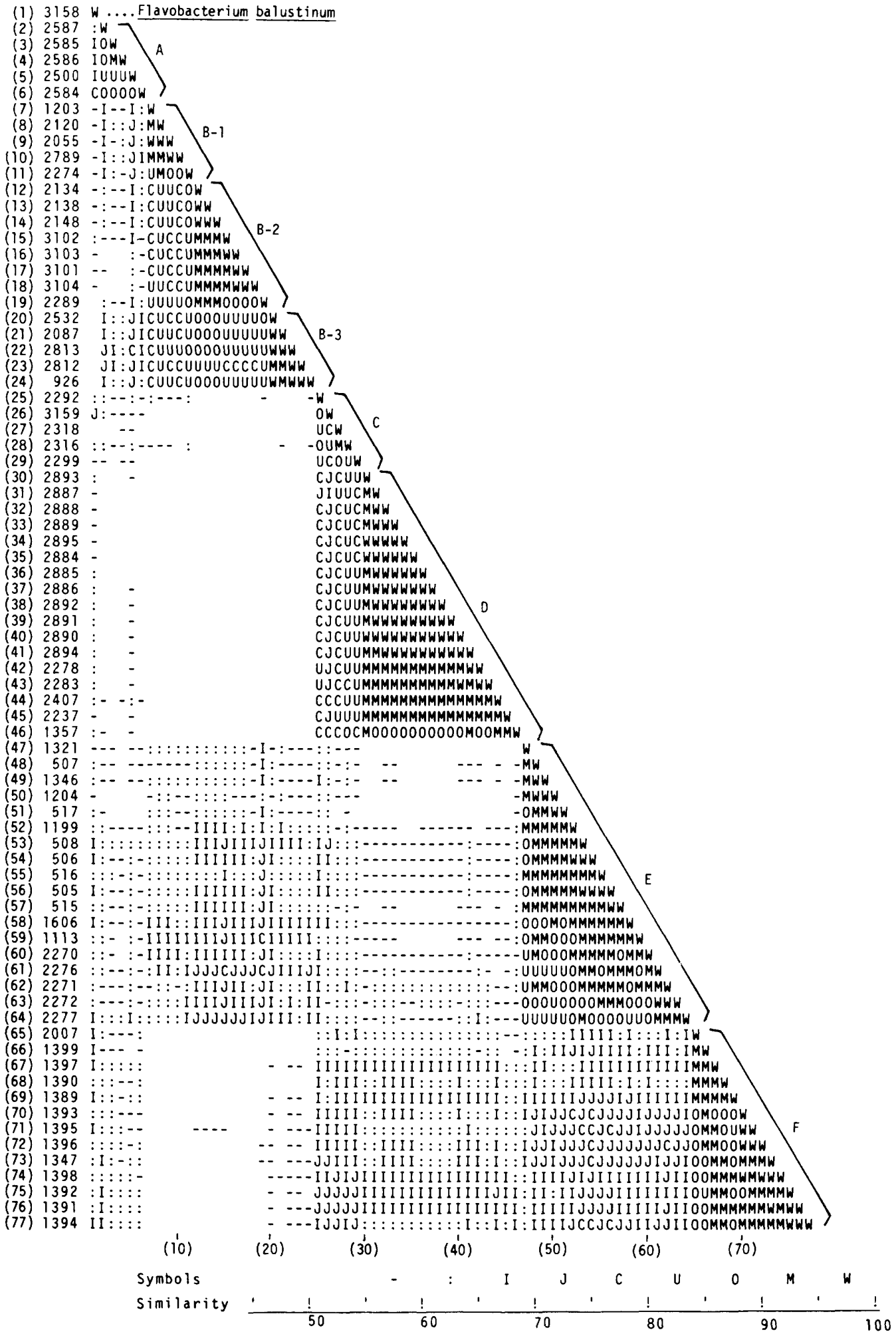

FIG. 2. Similarity matrix prepared by using the same method and data used to prepare Fig. 1. For an explanation of the clusters, see the legend to Fig. 1. The range of similarity percentages is symbolized as: W, $>95 \%$; M, 90.1 to $95.0 \%$; O, 85.1 to $90.0 \%$; U, 80.1 to $85.0 \%$; C, 75.1 to $80.0 \% ; \mathrm{J}, 70.1$ to $75.0 \% ; \mathrm{I}, 65.1$ to $70.0 \%$; :, 60.1 to $65.0 \%$;,- 55.1 to $60.0 \%$; open space, $<55 \%$. 
TABLE 2. Base ratios and DNA homologies of $S$. spiritivorum, S. multivorum, S. mizutae, Cytophaga spp., $F$. indologenes, and four other Flavobacterium species

\begin{tabular}{|c|c|c|c|c|c|c|c|c|}
\hline \multirow{3}{*}{$\begin{array}{c}\text { Source of } \\
\text { unlabeled DNA }\end{array}$} & \multirow{3}{*}{$\begin{array}{l}\text { GIFU } \\
\text { strain } \\
\text { no. }\end{array}$} & \multirow{3}{*}{$\begin{array}{l}\mathrm{G}+\mathrm{C} \\
\text { content } \\
(\text { mol\%) }\end{array}$} & \multicolumn{6}{|c|}{ Rebinding ratio with labeled DNA from strain: ${ }^{b}$} \\
\hline & & & \multirow{2}{*}{$\begin{array}{c}\text { GIFU } \\
3101^{\mathrm{T}} \\
\text { (prepn A) }\end{array}$} & \multicolumn{2}{|c|}{ GIFU 2138} & \multirow{2}{*}{$\begin{array}{c}\text { GIFU } \\
2812^{T} \\
\text { (prepn B) }\end{array}$} & \multirow{2}{*}{$\begin{array}{l}\text { GIFU } 926 \\
\text { (prepn B) }\end{array}$} & \multirow{2}{*}{$\begin{array}{c}\text { GIFU } \\
1203^{\mathrm{T}} \\
\text { (prepn B }\end{array}$} \\
\hline & & & & Prepn A & Prepn B & & & \\
\hline \multirow[t]{8}{*}{ S. spiritivorum } & $3101^{\mathrm{T}}$ & 40.2 & 100 & & 74 & & & \\
\hline & 2134 & 40.0 & 81 & 94 & 90 & 19 & & 9 \\
\hline & 2138 & 40.3 & 91 & 100 & 100 & & 14 & \\
\hline & 2148 & 40.0 & 73 & 89 & 88 & & & 12 \\
\hline & 2289 & 40.3 & 80 & 81 & 74 & 7 & & \\
\hline & 3102 & 40.5 & 85 & & 73 & & & \\
\hline & 3103 & 40.2 & 97 & & 70 & & & \\
\hline & 3104 & 39.9 & 82 & & 64 & & & \\
\hline \multirow[t]{5}{*}{ S. multivorum } & $2812^{\mathrm{T}}$ & 42.2 & & 34 & 18 & 100 & 78 & 10 \\
\hline & 2532 & 41.7 & & & & 100 & 97 & \\
\hline & 2813 & 40.8 & & 24 & 18 & 89 & 79 & \\
\hline & 2087 & 42.0 & & 27 & 15 & 74 & 83 & 15 \\
\hline & 926 & 39.8 & & & & 66 & 100 & 10 \\
\hline \multirow[t]{5}{*}{ S. mizutae } & $1203^{\mathrm{T}}$ & 40.0 & & 19 & 11 & & 10 & 100 \\
\hline & 2055 & 41.5 & & 28 & 19 & 8 & & \\
\hline & 2789 & 41.4 & & 17 & 12 & & & 79 \\
\hline & 2120 & 39.0 & & & & 6 & & 32 \\
\hline & 2274 & 40.5 & 11 & & 7 & 6 & & \\
\hline \multirow[t]{2}{*}{ C. johnsonae } & $2500^{\mathrm{T}}$ & 36.8 & & & & & & \\
\hline & 2584 & 37.1 & & & & 3 & & \\
\hline $\begin{array}{l}\text { "C. lytica" } \\
\text { ATCC } 23178^{\mathrm{T}}\end{array}$ & $2490^{\mathrm{T}}$ & 33.9 & & 17 & 10 & & & \\
\hline $\begin{array}{l}\text { C. marinoflava } \\
\text { ATCC } 19326^{\mathrm{T}} \\
\end{array}$ & $2502^{\mathrm{T}}$ & 39.5 & & 8 & 4 & 2 & & 3 \\
\hline $\begin{array}{c}\text { Cytophaga sp. } \\
\text { NCMB } 249 \\
\end{array}$ & 2506 & 40.3 & & & & & & \\
\hline \multirow{2}{*}{$\begin{array}{l}\text { F. meningosep- } \\
\text { ticum }\end{array}$} & $506^{\mathrm{T}}$ & 37.1 & & & & & 4 & 3 \\
\hline & 507 & 36.4 & & 11 & 6 & & & 6 \\
\hline \multirow[t]{7}{*}{$F$. indologenes } & $1347^{\mathrm{T}}$ & 37.6 & 4 & & 7 & & & \\
\hline & 1389 & & & & & & & \\
\hline & 1391 & & & & & & & \\
\hline & 1395 & & & & & & & \\
\hline & 1397 & 38.3 & & & & 5 & & 6 \\
\hline & 1399 & & & & & & & \\
\hline & 2007 & 37.3 & & 14 & 8 & 4 & 4 & \\
\hline F. balustinum & $3158^{\mathrm{T}}$ & 34.7 & 2 & & 5 & & & \\
\hline \multirow[t]{2}{*}{ F. odoratum } & $1357^{\mathrm{T}}$ & 37.6 & & 7 & 4 & & & 5 \\
\hline & 2283 & 34.2 & & & & & & 4 \\
\hline \multirow[t]{2}{*}{ F. breve } & $3159^{\mathrm{T}}$ & 33.8 & 4 & & 7 & & & \\
\hline & 2318 & 35.0 & & & & 6 & & \\
\hline $\begin{array}{l}\text { L. pneumophi- } \\
\text { la ATCC } \\
33152^{\mathrm{T}} \\
\end{array}$ & $2522^{\mathrm{T}}$ & 37.6 & & & & 1 & & \\
\hline $\begin{array}{l}\text { B. cereus } \\
\text { ATCC } 14579^{\mathrm{T}}\end{array}$ & & 34.5 & & & & 2 & & \\
\hline
\end{tabular}

${ }^{a} \mathrm{G}+\mathrm{C}$ contents were estimated from melting temperatures in $1 \times \mathrm{SSC}$.

${ }^{b}$ Homologies were estimated from DNA-DNA hybridization ratios by a membrane filter method. In each case, for preparation A normal hybridization was allowed to proceed for $40 \mathrm{~h}$ at $55^{\circ} \mathrm{C}$; for preparation $\mathrm{B}$, after normal hybridization was allowed to proceed for $40 \mathrm{~h}$ at $55^{\circ} \mathrm{C}$, the filters were heated for $30 \mathrm{~min}$ at $65^{\circ} \mathrm{C}$ to eliminate unstable hybrids.

around the growth was produced. Anaerobic respiration of nitrate, nitrite, or fumarate was determined in $1 \%$ Casitone (Difco) $-0.3 \%$ yeast extract (Difco) broth supplemented with $0.2 \%$ nitrate, $0.2 \%$ nitrite, or $0.08 \%$ sodium fumarate (3). These cultures were incubated in an anaerobic glove box (Forma Scientific). Other biochemical properties were determined by methods described previously $(31,33)$.

API ZYM chromogenic enzyme substrate strips (Appareils et Procédés d'Identification; La Balme les Grottes, Montalieu Vercieu, France) were used to determine the enzymatic activities of test organisms. 
TABLE 2-Continued

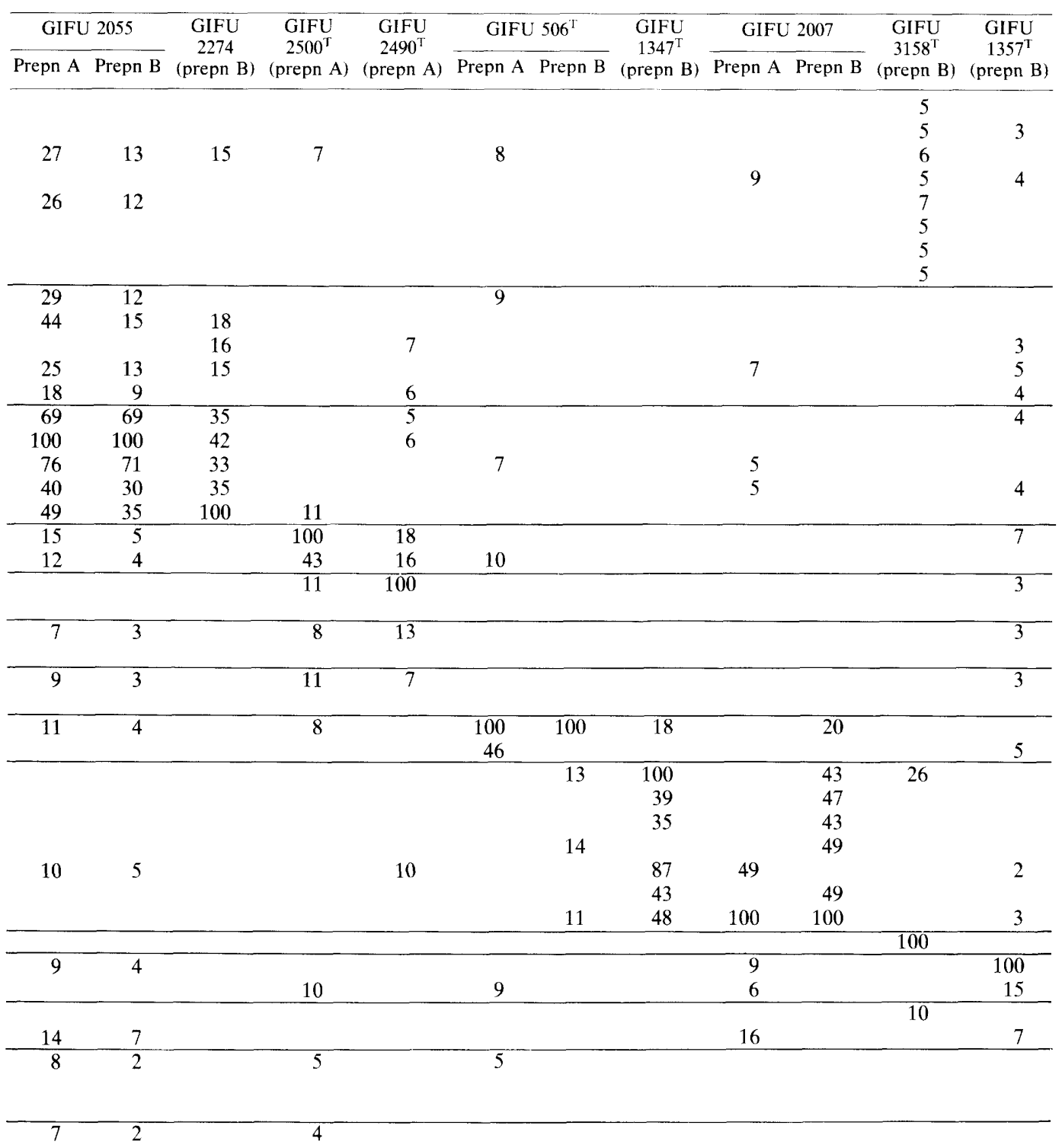

Cultures were grown on heart infusion agar for $20 \mathrm{~h}$ and then suspended in sterile distilled water at a turbidity equal to a MacFarland no. 5 standard. Then 2 drops of each suspension were distributed into each of the 20 cupules on a strip with a sterile Pasteur pipette. After incubation for $4 \mathrm{~h}$ at $37^{\circ} \mathrm{C}$ in a humid atmosphere, 1 drop each of two reagents (ZYM A and ZYM $B$ ) was added. Then the strips were exposed to the light from two 500 -W bulbs for about $20 \mathrm{~s}$ to reduce the residual yellow color in negative reactions. Scores for enzymatic activity ( 0 through 5 ) were recorded accord- ing to the color table of the manufacturer; reactions which gave scores of 2 through 5 were recorded as positive.

Susceptibilities to antimicrobial agents. Susceptibilities to 17 antimicrobial agents (see Table 5) were estimated by the method of Bauer et al. (2). To do this, Sensi-Discs and Mueller-Hinton II agar plates (BBL Microbiology Systems, Cockeysville, Md.) were used. Escherichia coli GIFU 3005 (= ATCC 25922), Pseudomonas aeruginosa GIFU 3006 (= ATCC 27853), and Staphylococcus aureus GIFU 3007 (=ATCC 25923) 
TABLE 3. Percent compositions of long-chain bases in the total lipids extracted from 10 strains of three Sphingobacterium species

\begin{tabular}{|c|c|c|c|c|c|c|c|c|c|c|}
\hline \multirow{3}{*}{$\begin{array}{l}\text { Long- } \\
\text { chain } \\
\text { base }^{a}\end{array}$} & \multicolumn{10}{|c|}{$\%$ In total lipids } \\
\hline & \multicolumn{4}{|c|}{ S. spiritivorum } & \multicolumn{4}{|c|}{ S. multivorum } & \multicolumn{2}{|c|}{ S. mizutae } \\
\hline & $\begin{array}{c}\text { GIFU } \\
2134\end{array}$ & $\begin{array}{c}\text { GIFU } \\
2138\end{array}$ & $\begin{array}{c}\text { GIFU } \\
2148\end{array}$ & $\begin{array}{l}\text { GIFU } \\
3101^{\mathrm{T}}\end{array}$ & $\begin{array}{c}\text { GIFU } \\
926\end{array}$ & $\begin{array}{l}\text { GIFU } \\
2087\end{array}$ & $\begin{array}{l}\text { GIFU } \\
2812^{\mathrm{T}}\end{array}$ & $\begin{array}{c}\text { GIFU } \\
2813\end{array}$ & $\begin{array}{l}\text { GIFU } \\
1203^{\mathrm{T}}\end{array}$ & $\begin{array}{c}\text { GIFU } \\
2789\end{array}$ \\
\hline d-15:0br & $\mathrm{t}^{b}$ & $\mathrm{t}$ & $\mathrm{t}$ & $\mathrm{t}$ & $\mathrm{t}$ & $\mathrm{t}$ & $\mathrm{t}$ & $\mathrm{t}$ & $\mathrm{t}$ & $t$ \\
\hline d-16-1(?) & $\mathrm{t}$ & $\mathrm{t}$ & $\mathrm{t}$ & $\mathrm{t}$ & 2 & $\mathrm{t}$ & $\mathrm{t}$ & $\mathrm{t}$ & $\mathrm{t}$ & $\mathrm{t}$ \\
\hline$d-16: 0$ & 4 & 3 & 5 & 4 & 5 & 4 & 8 & 5 & $\mathrm{t}$ & $\mathrm{t}$ \\
\hline d-17:0br & 82 & 68 & 82 & 80 & 78 & 79 & 90 & 85 & 98 & 96 \\
\hline $\mathrm{d}-18: 1(?)$ & 1 & $\mathrm{t}$ & 2 & 1 & 2 & 2 & $\mathrm{t}$ & $\mathrm{t}$ & $\mathrm{t}$ & $\mathrm{t}$ \\
\hline d-18:0 & 13 & 25 & 11 & 15 & 14 & 15 & 2 & 10 & 3 & 4 \\
\hline d-19:0br & $\mathrm{t}$ & 4 & $t$ & $\mathrm{t}$ & $\mathrm{t}$ & $t$ & $\mathrm{t}$ & $\mathrm{t}$ & $\mathrm{t}$ & $\mathrm{t}$ \\
\hline
\end{tabular}

${ }^{a} \mathrm{~d}$, Dihydroxy or two hydroxyl groups in the long-chain base. The number to the left of the colon indicates the number of carbon atoms in the chain, and the number to the right of the colon indicates the number of double bonds; br indicates a methyl branched-chain group in the long-chain base, and ? indicates a tentative identification.

${ }^{b} \mathrm{t}$, Trace (less than $1.0 \%$ ).

were used as the reference cultures to standardize the tests, according to the instructions of the manufacturer.

Cellular lipids and fatty acid analysis. The long-chain base components of the cellular sphingolipids were obtained from acid hydrolysates of acetone-dried powders of the test strains by the method used to obtain the sphingoglycolipids of Pseudomonas paucimobilis (31). The long-chain bases were demonstrated by thinlayer chromatography and identified by gas-liquid chromatography and gas chromatography-mass spectrometry of their trimethylsilyl ether derivatives (36). To estimate the contents of cellular sphingolipids, the amounts of alkaline-stable lipids in the total lipids and the phosphorus contents of both total lipids and alkaline-stable lipids were quantitated with strain GIFU 2138. Cells of strain GIFU 2138 grown on PYG medium $(1.0 \%$ Bacto-Peptone [Difco], $0.5 \%$ yeast extract [Difco], $0.5 \%$ glucose, 1.5\% Bacto-Agar [Difco]) were harvested and lyophilized after $20 \mathrm{~h}$ of incubation at $30^{\circ} \mathrm{C}$. The cellular lipids from $3.9 \mathrm{~g}$ of lyophilized cells were extracted twice with $80 \mathrm{ml}$ of chloroformmethanol $(2: 1, \mathrm{vol} / \mathrm{vol})$ and washed by the method of Folch et al. (7). After the preparation was reduced to dryness, the lipids were hydrolyzed by shaking with $0.5 \mathrm{~N} \mathrm{KOH}$ in $50 \mathrm{ml}$ of chloroform-methanol $(2: 1, \mathrm{vol} /$ vol) for $3 \mathrm{~h}$ at room temperature. After neutralization with acetic acid and washing with 0.2 volume of water, the bottom layer was dried and dissolved in $50 \mathrm{ml}$ of chloroform-methanol $(2: 1, \mathrm{vol} / \mathrm{vol})$. The reaction mixture was washed twice with 0.2 volume of water. The bottom layer was evaporated, dried, and weighed; this fraction represented the alkaline-stable lipids. The phosphorus contents of the total lipids and alkalinestable lipids were estimated by the method of Allen (1).

Cellular fatty acid analyses of $S$. spiritivorum, $F$. indologenes, and $F$. meningosepticum strains were performed with a gas chromatograph (Hewlett-Packard, Avondale, Pa.) equipped with a fused silica capillary column, as described previously (30).

Cell-bound orange pigments. The solubilities of the cell-bound orange pigments of three $F$. indologenes strains (GIFU 1347 ${ }^{\mathrm{T}}$, GIFU 1359, and GIFU 2007) and
C. johnsonae GIFU $2500^{\mathrm{T}}$ were tested with organic solvents after growth on PYG plates. Cells were removed from each plate and treated with ethanol, methanol, diethyl ether, acetone, $n$-hexane, or chloroform. The visible absorption spectra of the acetone extracts of the four strains mentioned above and $F$. balustinum GIFU $3158^{\mathrm{T}}$ were determined with a Hitachi model 340 recording spectrophotometer. Spectra were determined before and after $20 \% \mathrm{KNO}$ was added to the acetone extracts.

DNA base composition and DNA homology. DNA was prepared and purified by phenol extraction from cells grown in heart infusion broth. The $\mathrm{G}+\mathrm{C}$ content of each DNA was determined by melting (denaturing) the DNA contained in $1 \times \mathrm{SSC}(0.15 \mathrm{M} \mathrm{NaCl}$ plus 15 $\mathrm{mM}$ trisodium citrate buffer) in a model $2400 \mathrm{~S}$ spectrophotometer (Gilford Instrument Laboratories, Inc., Oberlin, Ohio) equipped with a model 2527 thermoprogrammer. The melting temperature was converted to $\mathrm{G}+\mathrm{C}$ content by the formula of Marmur and Doty (16). Crude preparations of $F$. indologenes DNA contained unusual amounts of impurities, which made the solution turbid and strongly stimulated nonspecific binding of labeled DNA to filters. Nonspecific binding was prevented by heating the DNA in $0.1 \times \mathrm{SSC}$, which denatured the DNA and markedly decreased its viscosity. After centrifugation at $30,000 \times g$ for $10 \mathrm{~min}$, 0.33 volume of $10 \times \mathrm{SSC}$ was added to the clear supernatant. The mixture was incubated at $60^{\circ} \mathrm{C}$ for several hours for annealing, and the DNA was then spooled out.

Tritium-labeled DNA was extracted from cells grown in the presence of $\left[{ }^{3} \mathrm{H}\right]$ thymidine or $\left[{ }^{3} \mathrm{H}\right]$ uridine. DNA-DNA hybridization experiments were performed as described previously (20). Incubation was performed at $55^{\circ} \mathrm{C}$ (which is significantly lower than the denaturation temperature minus $25^{\circ} \mathrm{C}$ ) to detect relatedness between relatively different organisms ( $\mathrm{T}$. Kaneko, unpublished data). The heat stabilities of the hybrids were examined by reheating the filters at $65^{\circ} \mathrm{C}$ for 30 min after counting (20).,

Numerical analysis. Similarity values were calculated before and after omitting the 36 phenotypic characters for which all 77 test strains gave the same results 
(either uniformly positive or uniformly negative). The susceptibilities of the 77 test strains to 17 antimicrobial agents were excluded in every calculation.

\section{RESULTS AND DISCUSSION}

Evidence for distinct taxonomic groups. (i) $\mathrm{Nu}$ merical analysis. The dendrogram in Fig. 1, which was prepared by simple matching and average-linkage methods for effective data, illustrates the phenotypic relationships among the 77 strains which we studied.

Cluster B, which is composed of three subclusters of Sphingobacterium, is clearly separated from cluster A, which represents $C$. johnsonae. Subclusters B-1, B-2, and B-3 each corresponds to a separate species. Although the final within-species level of similarity was $87.3 \%$ for subcluster B-1 (S. mizutae), the average level of similarity among four strains (excluding strain GIFU 2274) was $93.6 \%$, and the level of similarity between strains GIFU 2274 and GIFU 2120 was $90 \%$ or more (Fig. 2). The within-species level of similarity for subcluster B-2 ( $S$. spiritivorum) was $88.5 \%$, because strain GIFU 2289 was incorporated at this level. However, the levels of similarity for strain GIFU 2289 compared with strains GIFU 2134, GIFU 2138, and GIFU 2148 were between 90 and $95 \%$ (Fig. 2). The average level of similarity among the five strains of $S$. multivorum (subcluster B-3) was $95.1 \%$.

The 13 strains of group IIb formed a welldefined cluster (cluster F) at a similarity level of $89.2 \%$. The level of similarity between group IIb (cluster F) and $F$. meningosepticum (cluster E) was $68.2 \%$, and the level of similarity between group $\mathrm{IIb}$ and $C$. johnsonae (cluster $\mathrm{A}$ ) was $53.7 \%$. F. balustinum GIFU $3158^{\mathrm{T}}$ is associated primarily with cluster A ( $68 \%$ ), not cluster F. As a result of chaining, the dendrogram suggests the presence of subclusters in cluster F. However, two- and three-dimensional coordination of the dendrogram indicated no substantial subclusters in cluster F (T. Kaneko, N. Niki, unpublished data), and the similarity matrix (Fig. 2) also did not indicate any clear subclusters.

Our numerical analysis (Fig. 1 and 2) indicates that the genus Sphingobacterium should be placed in the family Cytophagaceae together with the genus Flavobacterium, as proposed by Callies and Mannheim (4).

(ii) Base ratios and relative binding ratios of DNAs. The $\mathrm{G}+\mathrm{C}$ contents of the DNAs of strains of three Sphingobacterium species, five Flavobacterium species, four Cytophaga species, L. pneumophila GIFU $2522^{\mathrm{T}}$, and $B$. cereus ATCC $12579^{1}$ and DNA-DNA homology values are shown in Table 2.

The $\mathrm{G}+\mathrm{C}$ contents of the 18 strains of three Sphingobacterium species studied are slightly higher than those of the Flavobacterium species, C. johnsonae and "C. lytica." The $\mathrm{G}+\mathrm{C}$ content of $F$. balustinum GIFU $3158^{\mathrm{T}}$ is about $3 \mathrm{~mol} \%$ lower than that of the $F$. indologenes strains tested.

High levels of homology were observed among the eight strains of $S$. spiritivorum and five strains of $S$. multivorum studied. The levels of homology between $S$. spiritivorum GIFU 2289 and $S$. spiritivorum GIFU $3101^{\mathrm{T}}$ and GIFU 2138 were 80 and $74 \%$, respectively, although the average level of similarity for strain GIFU 2289 in the numerical analysis of 107 phenotypic characteristics was lower than the average levels of similarity among the other four $S$. spiritivorum strains tested. Among the five strains of S. mizutae studied, both strain GIFU 2120 and strain GIFU 2274 gave homology values of only 30 to $42 \%$ compared with the other three strains. The lower levels of homology within this species may reflect biochemical dissimilarities between these two strains and the other $S$. mizutae strains (see Table 5) and suggest that strains GIFU 2120 and GIFU 2274 may represent a fourth species of Sphingobacterium which has not been described yet.

The levels of homology among the seven strains of $F$. indologenes studied ranged from 35 to $49 \%$. However, some genetic relatedness is evident, based on the values of 11 to $14 \%$ among three of these strains and $F$. meningosepticum GIFU $506^{\mathrm{T}}$ and $26 \%$ between $F$. indologenes GIFU $1347^{\mathrm{T}}$ and $F$. balustinum GIFU $3158^{\mathrm{T}}$. Because of this evidence and the major phenotypic similarities of these strains, we assigned them to a single species. A much lower level of homology between $F$. balustinum and group IIb (21) was obtained by using different experimental conditions (22).

(iii) Cellular lipid composition. A total of 18 strains belonging to three Sphingobacterium species contained major amounts of long-chain bases in their cellular lipids, as determined by thin-layer chromatography. These components were not detected in the other 59 strains studied. Cells of $C$. johnsonae reportedly contain sulfonolipids (15). The relative amounts of the longchain base components of nine strains belonging to three Sphingobacterium species are summarized in Table 3. The amount of total lipid extracted from $3.9 \mathrm{~g}$ of freeze-dried cells of strain GIFU 2138 was $466.5 \mathrm{mg}$, of which $295 \mathrm{mg}$ (63.2\%) was alkaline stable. The phosphorus contents of the total lipids and alkaline-stable lipids were 9.5 and $2.0 \mathrm{mg}$, respectively.

The amounts of branched-chain fatty acids in $F$. indologenes GIFU $1347^{\mathrm{T}}$ and $F$. meningosepticum GIFU $506^{\mathrm{T}}$ were more than $80 \%$ of the total cellular fatty acid contents, but the percentage of branched-chain acids in $C$. johnsonae 
TABLE 4. Cellular fatty acid compositions of the type and reference strains of the three Sphingobacterium species, C. johnsonae, and two species of Flavobacterium

\begin{tabular}{|c|c|c|c|c|c|c|c|c|c|c|c|}
\hline \multirow{3}{*}{ Fatty acid $a$} & \multicolumn{11}{|c|}{$\%$ Of total lipids } \\
\hline & \multicolumn{5}{|c|}{ S. spiritivorum } & \multicolumn{2}{|c|}{ S. multivorum } & \multicolumn{2}{|c|}{ S. mizutae } & \multicolumn{2}{|c|}{ C. johnsonae } \\
\hline & $\begin{array}{l}\text { GIFU } \\
3101^{\mathrm{T}}\end{array}$ & $\begin{array}{l}\text { GIFU } \\
2138\end{array}$ & $\begin{array}{l}\text { GIFU } \\
3102\end{array}$ & $\begin{array}{c}\text { GIFU } \\
3103\end{array}$ & $\begin{array}{l}\text { GIFU } \\
3104\end{array}$ & $\begin{array}{l}\text { GIFU } \\
2812^{\mathrm{T}}\end{array}$ & $\begin{array}{c}\text { GIFU } \\
926\end{array}$ & $\begin{array}{l}\text { GIFU } \\
1203^{\mathrm{T}}\end{array}$ & $\begin{array}{l}\text { GIFU } \\
2055\end{array}$ & $\begin{array}{l}\text { GIFU } \\
2500^{\mathrm{T}}\end{array}$ & $\begin{array}{c}\text { GIFU } \\
2584\end{array}$ \\
\hline $14: 0$ & 2 & 2 & 1 & 2 & 1 & $-b$ & 5 & - & - & 4 & 5 \\
\hline $15: 0$ & - & - & - & - & - & - & - & - & - & 1 & 1 \\
\hline $16: 1$ & 20 & 24 & 12 & 16 & 5 & 13 & 29 & 17 & 15 & 27 & 35 \\
\hline $16: 0$ & 4 & 5 & 3 & 3 & 2 & 2 & 11 & 3 & 1 & 23 & 16 \\
\hline $17: 0$ & - & - & - & - & - & - & - & - & - & - & - \\
\hline $18: 2$ & - & - & 1 & - & 1 & - & - & - & - & - & - \\
\hline $18: 1$ & - & - & - & - & - & - & - & - & - & - & - \\
\hline 18:0 & - & - & - & - & - & - & - & - & - & - & - \\
\hline $\mathrm{i}-13: 0$ & - & - & - & - & - & - & - & - & - & - & - \\
\hline $\mathrm{i}-15: 0$ & 36 & 25 & 42 & 40 & 50 & 27 & 18 & 26 & 32 & 32 & 15 \\
\hline $\mathrm{a}-15: 0$ & - & - & - & - & 1 & - & - & - & - & - & - \\
\hline$i-16: 0$ & - & - & - & - & - & - & - & - & - & 3 & 4 \\
\hline $\mathrm{i}-17: 1$ & - & - & 2 & 1 & 2 & 3 & - & 2 & 4 & 1 & - \\
\hline$i-17: 0$ & - & - & - & - & - & - & - & - & - & - & 1 \\
\hline 2-OH-14:0 & - & 1 & - & - & - & - & 1 & - & - & - & - \\
\hline 3-OH-14:0 & - & - & - & - & - & - & - & - & - & 3 & 4 \\
\hline $3-\mathrm{OH}-16: 0$ & 2 & 3 & 1 & 1 & 1 & - & 2 & 1 & - & 5 & 6 \\
\hline $\mathrm{i}-2-\mathrm{OH}-15: 0$ & 24 & 28 & 26 & 25 & 25 & 35 & 19 & 30 & 29 & 2 & 1 \\
\hline $\mathrm{i}-3-\mathrm{OH}-15 ; 0$ & 3 & 3 & 2 & 3 & 4 & 4 & 7 & 3 & 2 & 5 & 6 \\
\hline $\mathrm{i}-3-\mathrm{OH}-17: 0$ & 4 & 3 & 6 & 4 & 5 & 10 & 1 & 11 & 11 & 1 & 1 \\
\hline
\end{tabular}

${ }^{a}$ The number to the left of the colon indicates the number of carbon atoms, and the number to the right of the colon indicates the number of double bonds. i, A methyl group is present at the penultimate (iso) carbon atom; a, a methyl group is present at the antepenultimate (anteiso) carbon atom; 2-OH and 3-OH, a hydroxyl group is present at carbon atoms 2 and 3, respectively.

${ }^{b}-$, Not detected or present at a level less than $1 \%$.

TABLE 5. Antimicrobial agent susceptibilities of 18 strains of three Sphingobacterium species and 54 strains of five Flavobacterium species ${ }^{a}$

\begin{tabular}{|c|c|c|c|c|c|c|c|c|c|c|}
\hline \multirow[t]{2}{*}{ Drug } & \multirow{2}{*}{ Conen } & \multicolumn{3}{|c|}{$\begin{array}{l}\text { S. spiritivorum } \\
\qquad(n=8)^{b}\end{array}$} & \multicolumn{3}{|c|}{$\begin{array}{l}\text { S. multivorum } \\
(n=5)\end{array}$} & \multicolumn{3}{|c|}{$\begin{array}{l}\text { S. mizutae } \\
(n=5)\end{array}$} \\
\hline & & $\mathrm{S}^{\prime}$ & $\mathbf{I}^{c}$ & $\mathbf{R}^{c}$ & $\mathrm{~S}$ & I & $\mathrm{R}$ & $\mathrm{S}$ & I & $\mathrm{R}$ \\
\hline Sulfadiazin & $25 \mu \mathrm{g}^{d}$ & $7^{e}$ & 0 & 1 & $4^{e}$ & 0 & 1 & $4^{e}$ & 0 & 1 \\
\hline $\begin{array}{l}\text { Sulfamethoxazole- } \\
\text { trimethoprim }\end{array}$ & $\begin{array}{l}23.75 \mu \mathrm{g} \text { and } \\
1.25 \mu \mathrm{g}\end{array}$ & $7^{e}$ & 1 & 0 & $4^{e}$ & 0 & 1 & $4^{e}$ & 0 & 1 \\
\hline Nalidixic acid & $30 \mu \mathrm{g}$ & 0 & 4 & $4^{e}$ & 2 & $3^{\prime}$ & 0 & 2 & $2^{e}$ & 1 \\
\hline Erythromycin & $15 \mu \mathrm{g}$ & 0 & 0 & $8^{e}$ & 2 & $3^{e}$ & 0 & $2^{e}$ & 0 & 3 \\
\hline Clindamycin & $2 \mu \mathrm{g}$ & 0 & 1 & $7^{e}$ & 2 & 0 & $3^{e}$ & 2 & 0 & $3^{e}$ \\
\hline Streptomycin & $10 \mu \mathrm{g}$ & 0 & 0 & $8^{e}$ & 0 & $1^{e}$ & 4 & 0 & 1 & $4^{e}$ \\
\hline Amikacin & $10 \mu \mathrm{g}$ & 0 & 0 & $8^{e}$ & 0 & 0 & $5^{e}$ & 0 & 0 & $5^{e}$ \\
\hline Kanamycin & $30 \mu \mathrm{g}$ & 0 & 0 & $8^{e}$ & 0 & 0 & $5^{e}$ & 0 & 0 & $5^{e}$ \\
\hline Gentamicin & $10 \mu \mathrm{g}$ & 0 & 0 & $8^{e}$ & $3^{e}$ & 0 & 2 & 0 & 0 & $5^{e}$ \\
\hline Tetracycline & $30 \mu \mathrm{g}$ & 0 & 1 & $7^{e}$ & 2 & $2^{e}$ & 1 & $3^{e}$ & 1 & 1 \\
\hline Chloramphenicol & $30 \mu \mathrm{g}$ & 0 & $3^{e}$ & 5 & 3 & $1^{e}$ & 1 & $3^{e}$ & 0 & 2 \\
\hline Cephalothin & $30 \mu \mathrm{g}$ & 0 & 0 & $8^{e}$ & 1 & 0 & $4^{e}$ & 1 & 1 & $3^{e}$ \\
\hline Penicillin & $10 \mathrm{U}^{d}$ & 0 & 0 & $8^{e}$ & 0 & 0 & $5^{e}$ & 1 & 1 & $3^{e}$ \\
\hline Ampicillin & $10 \mu \mathrm{g}$ & 0 & 0 & $8^{e}$ & 0 & 0 & $5^{e}$ & 2 & 1 & $2^{e}$ \\
\hline Carbenicillin & $100 \mu \mathrm{g}$ & 0 & 0 & $8^{e}$ & $3^{e}$ & 2 & 0 & $4^{e}$ & 0 & 1 \\
\hline Colistin & $10 \mu \mathrm{g}$ & 0 & 0 & $8^{e}$ & 0 & 0 & $5^{e}$ & 0 & 0 & $5^{e}$ \\
\hline Polymyxin B & $300 \mu \mathrm{g}$ & 0 & 0 & $8^{e}$ & 0 & 0 & $5^{e}$ & 0 & 0 & $5^{e}$ \\
\hline
\end{tabular}

${ }^{a}$ The strains tested are listed in Table 1.

${ }^{b}$ Number of strains tested.

c S, Number of strains susceptible; I, number of strains with intermediate susceptibility; R, number of strains resistant.

${ }^{d}$ Amount of drug per disk.

e Category which included the type strain. 
TABLE 4-Continued

\begin{tabular}{|c|c|c|c|c|c|c|c|c|c|c|}
\hline \multicolumn{8}{|c|}{$F$. indologenes } & \multicolumn{3}{|c|}{ F. meningosepticum } \\
\hline $\begin{array}{l}\text { GIFU } \\
1347^{\mathrm{T}}\end{array}$ & $\begin{array}{c}\text { GIFU } \\
1389\end{array}$ & $\begin{array}{l}\text { GIFU } \\
1391\end{array}$ & $\begin{array}{l}\text { GIFU } \\
1394\end{array}$ & $\begin{array}{l}\text { GIFU } \\
1395\end{array}$ & $\begin{array}{c}\text { GIFU } \\
1397\end{array}$ & $\begin{array}{c}\text { GIFU } \\
1399 \\
\end{array}$ & $\begin{array}{l}\text { GIFU } \\
2007\end{array}$ & $\begin{array}{l}\text { GIFU } \\
506^{\mathrm{T}}\end{array}$ & $\begin{array}{c}\text { GIFU } \\
507\end{array}$ & $\begin{array}{r}\text { GIFU } \\
1606\end{array}$ \\
\hline - & - & - & - & - & - & - & - & - & - & - \\
\hline- & - & - & - & - & - & - & - & - & - & - \\
\hline 1 & - & 2 & - & 2 & 2 & 2 & 2 & 2 & 2 & 2 \\
\hline 3 & 2 & 2 & 1 & 2 & 1 & 1 & 1 & 2 & 1 & 3 \\
\hline - & - & - & - & - & - & - & - & - & - & - \\
\hline - & - & - & - & - & - & - & - & - & - & - \\
\hline - & - & - & - & - & - & - & - & - & - & - \\
\hline- & - & - & - & - & - & - & - & - & - & - \\
\hline 2 & 1 & 2 & 2 & 1 & - & 1 & 1 & 2 & 3 & 2 \\
\hline 49 & 44 & 47 & 54 & 43 & 37 & 45 & 42 & 40 & 46 & 39 \\
\hline- & - & - & - & 1 & - & - & - & 3 & 1 & 2 \\
\hline 3 & 3 & 2 & - & 2 & 3 & - & 2 & 2 & 2 & 4 \\
\hline 14 & 18 & 13 & 14 & 12 & 14 & 16 & 12 & 3 & 3 & 3 \\
\hline 1 & 3 & 1 & 1 & 2 & 2 & - & 2 & 1 & - & 1 \\
\hline- & - & - & - & - & - & - & - & - & - & - \\
\hline- & - & - & - & - & - & - & - & - & - & - \\
\hline- & - & 1 & - & - & - & 1 & 1 & 4 & 3 & 4 \\
\hline 10 & 5 & 11 & 7 & 15 & 19 & 16 & 16 & 22 & 22 & 20 \\
\hline 5 & 5 & 4 & 7 & 5 & 5 & 5 & 5 & 6 & 4 & 5 \\
\hline 11 & 12 & 12 & 9 & 12 & 12 & 11 & 12 & 11 & 7 & 8 \\
\hline
\end{tabular}

TABLE 5-Continued

\begin{tabular}{|c|c|c|c|c|c|c|c|c|c|c|c|c|c|c|}
\hline \multicolumn{3}{|c|}{$\begin{array}{l}F \text {. indologenes } \\
(n=13)\end{array}$} & \multicolumn{3}{|c|}{$\begin{array}{c}F . \text { meningosepticum } \\
(n=18)\end{array}$} & \multicolumn{3}{|c|}{$\begin{array}{l}\text { F. balustinum } \\
(n=1)\end{array}$} & \multicolumn{3}{|c|}{$\begin{array}{l}\text { F. odoratum } \\
(n=17)\end{array}$} & \multicolumn{3}{|c|}{$\begin{array}{l}\text { F. breve } \\
(n=5)\end{array}$} \\
\hline $\mathrm{S}$ & I & $\mathrm{R}$ & S & 1 & $\mathrm{R}$ & $\mathrm{S}$ & I & $\mathrm{R}$ & S & I & $\mathbf{R}$ & $S$ & I & $\mathrm{R}$ \\
\hline $7^{e}$ & 0 & 6 & $14^{e}$ & 1 & 3 & $1^{e}$ & 0 & 0 & $1^{e}$ & 1 & 15 & $1^{e}$ & 0 & 4 \\
\hline $12^{e}$ & 0 & 1 & $17^{e}$ & 0 & 1 & $1^{e}$ & 0 & 0 & $1^{e}$ & 0 & 16 & $1^{e}$ & 0 & 4 \\
\hline $12^{e}$ & 1 & 0 & 7 & $4^{e}$ & 7 & $1^{e}$ & 0 & 0 & 0 & $4^{e}$ & 13 & 0 & $1^{e}$ & 4 \\
\hline 1 & 0 & $12^{e}$ & $13^{e}$ & 0 & 5 & $1^{e}$ & 0 & 0 & $2^{e}$ & 0 & 15 & $4^{e}$ & 0 & 1 \\
\hline 1 & 0 & $12^{e}$ & 4 & 2 & $12^{e}$ & $1^{e}$ & 0 & 0 & $1^{e}$ & 0 & 16 & $4^{e}$ & 0 & 1 \\
\hline 1 & 2 & $10^{e}$ & 0 & 0 & $18^{e}$ & 0 & $1^{e}$ & 0 & 0 & 0 & $17^{e}$ & 0 & 1 & $4^{e}$ \\
\hline 0 & 2 & $11^{e}$ & 1 & 1 & $16^{e}$ & 0 & 0 & $1^{e}$ & $1^{e}$ & 0 & 16 & 0 & 0 & $5^{e}$ \\
\hline 0 & 0 & $13^{e}$ & 0 & 0 & $18^{e}$ & 0 & 0 & $1^{e}$ & 0 & 0 & $17^{e}$ & 0 & 0 & $5^{e}$ \\
\hline $7^{e}$ & 0 & 6 & 3 & 0 & $15^{e}$ & $1^{e}$ & 0 & 0 & 0 & 0 & $17^{e}$ & 1 & 0 & $4^{e}$ \\
\hline 0 & 0 & $13^{e}$ & $1^{e}$ & 1 & 16 & 0 & 0 & $1^{e}$ & 0 & 0 & $17^{e}$ & 1 & $1^{e}$ & 3 \\
\hline 4 & 2 & $7^{e}$ & 2 & 3 & $13^{e}$ & 0 & 0 & $1^{e}$ & 1 & 2 & $14^{e}$ & $4^{e}$ & 0 & 1 \\
\hline 0 & 0 & $13^{e}$ & 0 & 1 & $17^{e}$ & $1^{e}$ & 0 & 0 & 0 & 0 & $17^{e}$ & 0 & 1 & $4^{e}$ \\
\hline 0 & 0 & $13^{e}$ & 1 & 0 & $17^{e}$ & 0 & 0 & $1^{e}$ & 0 & $1^{e}$ & 16 & 0 & 0 & $5^{e}$ \\
\hline 0 & 0 & $13^{e}$ & 0 & 0 & $18^{e}$ & $1^{e}$ & 0 & 0 & $1^{e}$ & 0 & 16 & 0 & $2^{e}$ & 3 \\
\hline 0 & 0 & $13^{e}$ & 3 & 3 & $12^{e}$ & $1^{e}$ & 0 & 0 & 0 & $1^{e}$ & 16 & $3^{e}$ & 0 & 2 \\
\hline 0 & 0 & $13^{e}$ & 0 & 0 & $18^{e}$ & 0 & 0 & $1^{e}$ & 0 & 0 & $17^{e}$ & 0 & 0 & $5^{e}$ \\
\hline 0 & 0 & $13^{e}$ & 0 & 0 & $18^{e}$ & $1^{e}$ & 0 & 0 & 0 & 0 & $17^{e}$ & 0 & 0 & $5^{e}$ \\
\hline
\end{tabular}


GIFU $2500^{\mathrm{T}}$ was approximately $34 \%$. Moreover, strain GIFU $2500^{\mathrm{T}}$ contained $\mathrm{C}_{16: 1}$ and $\mathrm{C}_{16: 0}$ acids in much higher concentrations than strains GIFU $1347^{\mathrm{T}}$ and GIFU $506^{\mathrm{T}}$ (Table 4). The major cellular fatty acid component of eight $F$. indologenes strains and three $F$. meningosepticum strains was i- $\mathrm{C}_{15: 0}$. However, cells of $F$. indologenes strains contained larger amounts of $\mathrm{i}-\mathrm{C}_{17: 1}$ and smaller amounts of $\mathrm{i}-2-\mathrm{OH}-\mathrm{C}_{15: 0}$ than cells of $F$. meningosepticum.

For convenience of comparison with two Flavobacterium species, some of the cellular fatty acid data (30) for three Sphingobacterium species and $C$. johnsonae are also shown in Table 4.

(iv) Cell-bound orange pigments. The orange pigments of $F$. indologenes, which are similar to those of $C$. johnsonae strains and $F$. balustinum strain GIFU $3158^{\mathrm{T}}$, never diffused into the agar medium. The orange pigment immediately turned deep red when the culture was exposed to 1 drop of a $3 \% \mathrm{KOH}$ solution and returned to the original orange color when 1 drop of $1.5 \mathrm{~N}$ $\mathrm{HCl}$ was added. The growth of $F$. indologenes at the top of semisolid Voges-Proskauer medium (Eiken) became red after Voges-Proskauer reagent $\mathrm{B}$ was added; this color change could be confused with a positive reaction. The orange

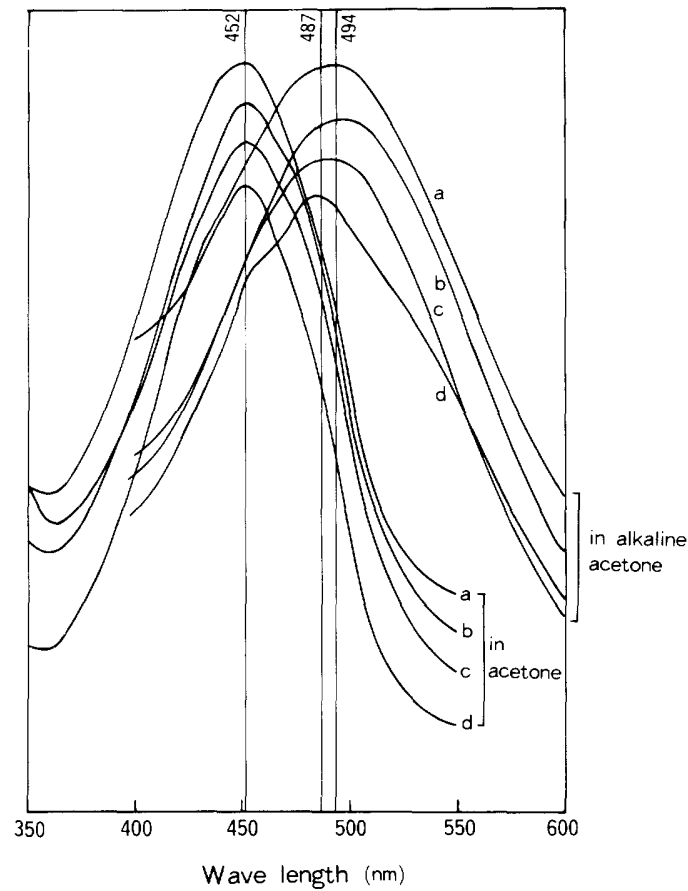

FIG. 3. Visible absorption spectra of acetone-extracted orange pigments from $F$. indologenes strains GIFU $1347^{\mathrm{T}}$ (lines a), GIFU 1395 (lines b), and GIFU 2007 (lines c) and $C$. johnsonae GIFU $2500^{\mathrm{T}}$ (lines d). Absorption spectra were recorded before and after treatment of acetone extracts with $20 \% \mathrm{KOH}$. pigments of $F$. indologenes and $C$. johnsonae were extracted from cells with methanol, ethanol, and acetone.

The visible absorption spectra of acetone extracts of strains GIFU $1347^{\mathrm{T}}$, GIFU 1395, GIFU 2007 , and GIFU $2500^{\mathrm{T}}$ had single peaks at approximately $451 \mathrm{~nm}$, which shifted to 490 to 494 , 494,489 to 494 , and $487 \mathrm{~nm}$, respectively, in alkalinized acetone (Fig. 3). The characteristic reversible color change of growth on solid media indicates that the intracellular orange pigment of $F$. indologenes strains, as well as the pigments of $F$. balustinum and $C$. johnsonae strains, may be of the flexirubin type (26).

(v) Antimicrobial agent susceptibilities. All eight strains of $S$. spiritivorum were resistant to 11 of the 17 antimicrobial agents tested. All five strains of $S$. multivorum were resistant to six drugs, and the five strains of $S$. mizutae studied were resistant to five drugs. Sulfadiazin $(25 \mu \mathrm{g})$ and sulfamethoxazole $(23.75 \mu \mathrm{g})$-trimethoprim $(1.25 \mu \mathrm{g})$ were the only drugs to which most strains of these three Sphingobacterium species were susceptible (Table 5).

Description of Sphingobacterium gen. nov. On the basis of the results described above and the phenotypic characteristics shown in Table 6, we propose the new genus Sphingobacterium (sphin - go $\cdot$ bac $\cdot$ te'rium. Gr. adj. sphingos of sphinx; Gr. neut. n. bakterion a small rod; N.L. neut. n. Sphingobacterium a sphingosine-containing bacterium).

The cells of species in this genus are gramnegative, nonsporeforming, straight rods that have no flagella but may exhibit sliding motility. Catalase is produced. These organisms are chemoorganotrophs without specialized growth factor requirements. Colonies usually become yellowish after several days at room temperature. Indole and acetylmethylcarbinol are not produced. The cells are nonproteolytic, and gelatin is not hydrolyzed. Acid is produced from carbohydrates oxidatively but not fermentatively. The major characteristics for generic differentiation of Sphingobacterium from Cytophaga and Flavobacterium are shown in Table 6.

Sphingobacterium cellular lipids contain sphingophospholipids whose ceramide moieties are chiefly branched-chain dihydrosaturated $\mathrm{C}_{17: 0}$ sphingosin, and the major acid is $\mathrm{i}-2-\mathrm{OH}-$ $\mathrm{C}_{15: 0}$.

Antisera against $F$. meningosepticum serogroups $\mathrm{A}$ through $\mathrm{F}$ do not agglutinate cells of strains of the Sphingobacterium species described here.

The DNA nucleotide base ratios $(\mathrm{G}+\mathrm{C}$ contents) of described species range from 39 to 42 mol\% (Table 2). The type species if Sphingobacterium spiritivorum (Holmes, Owen, and Hollis) comb. nov. 
Description of the three species assigned to Sphingobacterium gen. nov. Cells of the three species are 0.3 by 1.3 to $1.6 \mu \mathrm{m}$, occur singly or in pairs, and remain the same under different cultural conditions.

Strains of the three species share the following characteristics. Indophenol oxidase is produced. No growth occurs at $\mathrm{pH} 4.5$, at 4 or $41^{\circ} \mathrm{C}$, or on MacConkey agar (Nissui) or nalidixic acid (15 $\mathrm{mg} /$ liter)-cetrimide $(0.2 \mathrm{~g} /$ liter $)$ agar medium (Eiken). No growth is observed in media containing $5 \% \mathrm{NaCl}$ or $0.0075 \% \mathrm{KCN}$. Hydrogen sulfide production is usually detected by lead acetateimpregnated paper strips suspended over Kligler iron agar slants, but not in agar butts. Citrate, acetate, and malonate are not utilized. Esculin is hydrolyzed. Acid is produced from D-arabinose, cellobiose, fructose, galactose, glucose, lactose, maltose, mannose, melezitose, melibiose, raffinose, salicin, sucrose, trehalose, and xylose. Acid is not produced from adonitol, dulcitol, inositol, or sorbitol. Nitrate is not reduced to nitrite. L-Lysine decarboxylase, L-arginine dihydrolase, and L-orgnithine decarboxylase are not produced. Two-keto-gluconate is not produced from gluconate, and 3-ketolactonate is not produced from lactose.

The characteristics that are useful for differen-

TABLE 6. Phenotypic characteristics of the three species of Sphingobacterium, five species of Flavobacterium, and C. johnsonae

\begin{tabular}{|c|c|c|c|c|c|c|c|c|c|}
\hline \multirow[b]{2}{*}{ Character } & \multicolumn{9}{|c|}{$\%$ Of strains positive } \\
\hline & $\begin{array}{l}\text { S. spiriti- } \\
\text { vorum } \\
(n=8)^{a}\end{array}$ & $\begin{array}{l}\text { S. multi- } \\
\text { vorum } \\
(n=5)\end{array}$ & $\begin{array}{c}\text { S. mizutae } \\
(n=5)\end{array}$ & $\begin{array}{l}\text { C. john- } \\
\text { sonae } \\
(n=5)\end{array}$ & $\begin{array}{l}F . \text { meningo- } \\
\text { septicum } \\
(n=18)\end{array}$ & $\begin{array}{c}F . \text { indolo- } \\
\text { genes } \\
(n=13)\end{array}$ & $\begin{array}{c}F . \text { balus }- \\
\text { tinum } \\
(n=1)\end{array}$ & $\begin{array}{l}F . \text { odo- } \\
\text { ratum } \\
(n=17)\end{array}$ & $\begin{array}{l}\text { F. breve } \\
(n=5)\end{array}$ \\
\hline $\begin{array}{l}\text { Flexirubin type of pig- } \\
\text { ment }^{b}\end{array}$ & 0 & 0 & 0 & 100 & 0 & 100 & 100 & 0 & 0 \\
\hline Fruity odor ${ }^{b}$ & 0 & 0 & 0 & 0 & 0 & 46 & 0 & 100 & 100 \\
\hline Gliding translocation $^{b}$ & 0 & 0 & 0 & 100 & 0 & 0 & 0 & 0 & 0 \\
\hline $\begin{array}{l}\text { Growth in SMB con- } \\
\text { taining } 0.2 \% \text { glucose } \\
\text { and } 0.1 \% \text { ammonium } \\
\text { sulfate }^{c}\end{array}$ & 100 & 100 & 100 & 40 & 0 & 0 & 0 & 0 & 0 \\
\hline $\begin{array}{l}\text { Growth on skim acetate } \\
\text { agar }\end{array}$ & 0 & 0 & 0 & 100 & 94 & 100 & 100 & 76 & 60 \\
\hline Indole production ${ }^{b}$ & 0 & 0 & 0 & 0 & 100 & 100 & 100 & 0 & $100^{d}$ \\
\hline Gelatinase $^{b}$ & 0 & 0 & 0 & 100 & 100 & 100 & 100 & 100 & 100 \\
\hline \multicolumn{10}{|l|}{ Oxidative acidity from: } \\
\hline Galactose $^{b}$ & 100 & 100 & 100 & 100 & 0 & 0 & 0 & 0 & 0 \\
\hline Melezitose $\mathrm{e}^{b}$ & 100 & 100 & 100 & 0 & 0 & 0 & 0 & 0 & 0 \\
\hline Salicine $^{b}$ & 100 & 100 & 100 & 20 & 0 & 0 & 0 & 0 & 0 \\
\hline Inulin $^{b}$ & 38 & 100 & 0 & 80 & 0 & 0 & 0 & 0 & 0 \\
\hline Ethanol $(3 \%)^{e}$ & 100 & 0 & 0 & 20 & 100 & 46 & 100 & 0 & 0 \\
\hline Mannitol $^{e}$ & 100 & 0 & 0 & 40 & 100 & 31 & 0 & 0 & 0 \\
\hline Rhamnose $^{e}$ & 100 & 0 & 100 & 0 & 0 & 0 & 100 & 0 & 0 \\
\hline Glycogen ${ }^{e}$ & 0 & 100 & 0 & 100 & 0 & 100 & 0 & 0 & 80 \\
\hline D-Arabinose ${ }^{f}$ & 100 & 100 & 100 & 100 & 100 & 0 & 100 & 0 & 0 \\
\hline Fructose, mannose ${ }^{f}$ & 100 & 100 & 100 & 100 & 100 & 100 & 100 & 0 & 0 \\
\hline Glucose $^{f}$ & 100 & 100 & 100 & 100 & 100 & 100 & 100 & 0 & 100 \\
\hline Cellobiose $\mathrm{e}^{f}$ & 100 & 100 & 100 & 100 & 100 & 0 & 0 & 0 & 0 \\
\hline Lactose $^{f}$ & 100 & 100 & 100 & 0 & 100 & 0 & 0 & 0 & 0 \\
\hline Maltose $^{f}$ & 100 & 100 & 100 & 100 & 100 & 100 & 0 & 0 & 100 \\
\hline Sucrose $^{f}$ & 100 & 100 & 100 & 100 & 0 & 0 & 100 & 0 & 0 \\
\hline $\mathrm{DNase}^{b, e}$ & 100 & 100 & 0 & 0 & 100 & 100 & 100 & 100 & 100 \\
\hline Urease $^{f}$ & 100 & 100 & 20 & 20 & 0 & 0 & 0 & 100 & 100 \\
\hline Starch hydrolysis ${ }^{f}$ & 100 & 0 & 0 & 100 & 0 & 100 & 0 & 6 & 60 \\
\hline Malonate utilization $^{f}$ & 0 & 0 & 0 & 0 & 0 & 100 & 0 & 18 & 0 \\
\hline Esculin hydrolysis ${ }^{f}$ & 100 & 100 & 100 & 100 & 100 & 100 & 100 & 0 & 0 \\
\hline Egg yolk reaction ${ }^{f}$ & 0 & 0 & 0 & 0 & 0 & 100 & 0 & 0 & 0 \\
\hline
\end{tabular}

${ }^{a}$ Number of strains studied.

${ }^{b}$ Characteristics useful for differentiating the three genera Sphingobacterium, Cytophaga, and Flavobacterium.

c SMB, Standard mineral base medium (12).

${ }^{d}$ The four strains other than type strain produced very weak reactions.

${ }^{e}$ Characteristics useful for differentiating the three Sphingobacterium species.

${ }^{f}$ Characteristics useful for differentiating the five Flavobacterium species. 
TABLE 7. Variable characteristics among the strains of three Sphingobacterium species

\begin{tabular}{|c|c|c|c|c|}
\hline \multirow{2}{*}{ Species } & \multirow{2}{*}{$\begin{array}{l}\text { No. of } \\
\text { strains }\end{array}$} & \multirow{2}{*}{ Character } & \multicolumn{2}{|c|}{ Strain(s) producing the less common result } \\
\hline & & & Positive reaction & Negative reaction \\
\hline \multirow[t]{8}{*}{ S. spiritivorum } & 8 & Citrate (Christensen) & $2289^{a}$ & \\
\hline & & Acid from L-arabinose & 2289,3104 & \\
\hline & & Acid from inulin & $2134,2138,2148$ & \\
\hline & & $\begin{array}{l}\text { Green discoloration on rabbit } \\
\text { blood agar }\end{array}$ & 2289 & \\
\hline & & Fumarate respiration & 2289 & \\
\hline & & Valine arylamidase $\mathrm{e}^{b}$ & 2289 & \\
\hline & & Sliding translocation & & $2289,3101^{\mathrm{T}}$ \\
\hline & & Slant acid (Kligler iron agar) & & 3102 \\
\hline \multirow[t]{7}{*}{ S. multivorum } & 5 & Growth on MacConkey agar & 2087 & \\
\hline & & $\begin{array}{l}\text { Green discoloration on rabbit } \\
\text { blood agar }\end{array}$ & 926 & \\
\hline & & Fumarate respiration & 2532 & \\
\hline & & $\beta$-Glucosidase $\mathrm{e}^{b}$ & $926,2812^{\mathrm{T}}$ & \\
\hline & & $\mathrm{H}_{2} \mathrm{~S}$ (lead acetate paper) & & 2813 \\
\hline & & Tween 80 hydrolysis & & 2087 \\
\hline & & Growth on $40 \%$ bile agar & & $2812^{\mathrm{T}}$ \\
\hline \multirow[t]{10}{*}{ S. mizutae } & 5 & Citrate (Christensen) & 2274,2789 & \\
\hline & & Tween 80 & 2274 & \\
\hline & & Urease & 2274 & \\
\hline & & Acid from glycogen & 2789 & \\
\hline & & Slant acid (Kligler iron agar) & & $1203^{\mathrm{T}}$ \\
\hline & & $\mathrm{H}_{2} \mathrm{~S}$ (lead acetate paper) & & 2274 \\
\hline & & Acid from ribose & & 2274 \\
\hline & & $\begin{array}{l}\text { Green discoloration on rabbit } \\
\text { blood agar }\end{array}$ & & 2274,2789 \\
\hline & & Nitrite reduced to nitrogen gas & & 2120,2274 \\
\hline & & Valine arylamidase $\mathrm{e}^{b}$ & & 2120,2274 \\
\hline
\end{tabular}

${ }^{a}$ GIFU strain numbers (see Table 1).

${ }^{b}$ As determined by an API ZYM test.

tiating the three Sphingobacterium species are summarized in Table 6 , and the characteristics that are variable among the strains in each species are shown in Table 7.

(i) Sphingobacterium spiritivorum (Holmes, Owen, and Hollis) comb. nov. The characteristics of $S$. spiritivorum (spi $\cdot \mathrm{ri} \cdot \mathrm{ti}^{\prime}$ vo $\cdot \mathrm{rum}$. L. $\mathrm{n}$. spiritus spirit; L. adj. suffix vorus devouring, eating; M.L. adj. spiritivorus spirit-devouring, intended to refer to the ability of the organism to attack spirits [i.e., alcohol], producing acid in the process [10]) are as described above for the genus. Three of eight strains show distinctive spreading growth on $0.3 \%$ agar medium (Fig. 4a), but little or no spreading growth on medium containing $0.5 \%$ agar. At the edge of the spreading growth, the cells are arranged in a monolayer, which is not gliding $(5,9,17,24)$ but is typical for sliding translocation (9) (Fig. 4b). Three other strains show moderate spreading of semisolid agar medium.

This organism grows in the presence of $40 \%$ bile and produces acid in oxidation-fermentation medium from ethanol, glycerol, mannitol, and rhamnose. No acid is produced from D-ribose or glycogen. Urease and DNase are produced. Nitrite is not reduced to nitrogen gas.

The type strain is susceptible to sulfadiazin and sulfamethoxazole-trimethoprim but resistant to nalidixic acid and 14 other drugs (Table 5).

Isolated from human clinical specimens and hospital environments. The $\mathrm{G}+\mathrm{C}$ content of the DNA is 40.0 mol\%, as determined by the thermal denaturation method. The type strain is ATCC 33861 (= CDC E7288 = GIFU $3101=$ JCM 1277 = NCTC 11386).

(ii) Sphingobacterium multivorum (Holmes, Owen, and Weaver) comb. nov. In addition to the generic characteristics described above, S. multivorum (mul · ti · vo'rum. L. adj. multus many; L. vt. vorare to swallow; M.L. adj. multivorus intended to mean produces acid from many carbohydrates [11]) has the following features. No sliding translocation occurs on semisolid agar medium. A weak acid reaction is observed on Kligler iron agar slants. Starch and urea are hydrolyzed. Acid is produced from L-arabinose, inulin, and glycogen but not from ethanol, man- 

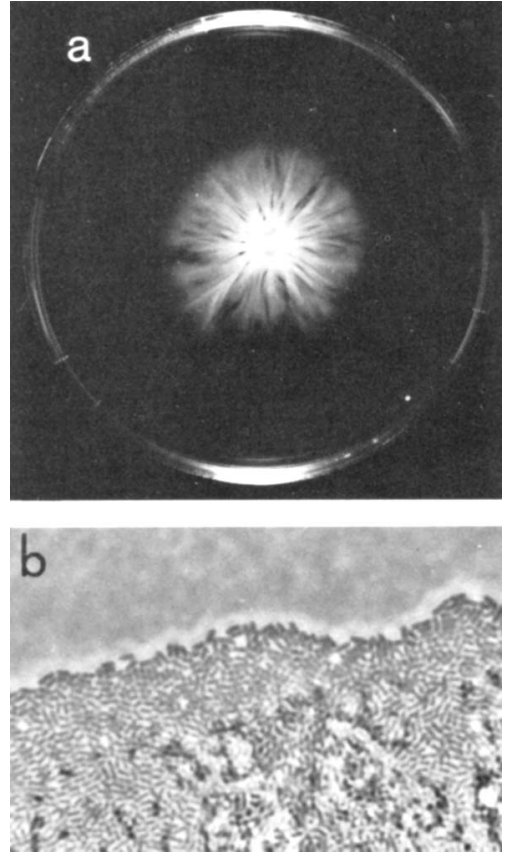

FIG. 4. (a) Spreading growth of S. spiritivorum GIFU 2138 on a semisolid agar motility medium $(0.3 \%$ agar) after $70 \mathrm{~h}$ of incubation at $25^{\circ} \mathrm{C}$. (b) Phasecontrast micrograph of $S$. spiritivorum GIFU 2138 cells in a monolayer at the edge of spreading growth on semisolid agar medium $(0.5 \%$ agar $)$ after $20 \mathrm{~h}$ at $25^{\circ} \mathrm{C}$. $\times 830$.

nitol, rhamnose, or D-ribose. Citrate is not utilized even on Christensen citrate agar medium. Nitrite is not reduced to nitrogen gas. Growth occurs in heart infusion broth adjusted to $\mathrm{pH}$ 5.0 .

The major fatty acids extracted from saponified whole cells of the type strain are $\mathrm{i}-2-\mathrm{OH}-$ $\mathrm{C}_{15: 0}, \mathrm{i}-\mathrm{C}_{15: 0}, \mathrm{C}_{16: 1}$, and $\mathrm{i}-3-\mathrm{OH}-\mathrm{C}_{17: 0}$. The type strain is susceptible to sulfadiazin, sulfamethoxazole-trimethoprim, carbenicillin and gentamicin but resistant to penicillin, ampicillin, cephalothin, amikacin, kanamycin, colistin, and polymyxin B. Intermediate levels of susceptibility are observed with streptomycin, tetracycline, chloramphenicol, erythromycin, and nalidixic acid.

The $\mathrm{G}+\mathrm{C}$ content is $42.2 \mathrm{~mol} \%$. The type strain is ATCC 33613 (= GIFU $2812=$ NCTC 11033).

(iii) Sphingobacterium mizutae sp. nov. S. mizutae (mi - zu'tae. N.L. adj. referring to Shunsuke Mizuta (18), Japanese pediatrician, who first reported a case of meningitis in a premature baby from whose spinal fluid the type strain of the species was isolated) has the characteristics described above for the genus, and in addition strains of this species tolerate $40 \%$ bile and produce acid from rhamnose in oxidation-fermentation medium. No acid is produced from ethanol, mannitol, or inulin. No growth occurs at $\mathrm{pH}$ 5.0. Sliding translocation on semisolid agar medium and fumarate respiration are not observed. Starch hydrolysis and DNase production are negative. Most strains do not oxidize glycogen or hydrolyze urea. Nitrate is not reduced to nitrite, but the type strain and some other strains reduce nitrite to nitrogen gas.

The type strain is susceptible to carbenicillin, chloramphenicol, tetracycline, erythromycin, sulfadiazin, and sulfamethoxazole-trimethoprim but is resistant to penicillin, ampicillin, cephalothin, streptomycin, amikacin, kanamycin, gentamicin, clindamycin, colistin, and polymyxin B.

Pathogenicity has not been defined. The natural habitat of this organism is not known, but it has been isolated from clinical specimens. The $\mathrm{G}+\mathrm{C}$ content of the DNA is in the range from 39.0 to $41.5 \mathrm{~mol} \%$. The type strain is ATCC 33299 (= GIFU 1203).

Description and discussion of Flavobacterium indologenes sp. nov. $F$. indologenes (in $\cdot \mathrm{do}^{\cdot} \cdot \mathrm{lo}^{\prime}$ ge $\cdot$ nes. M.L. neut. n. indolum indole; Gr. v.
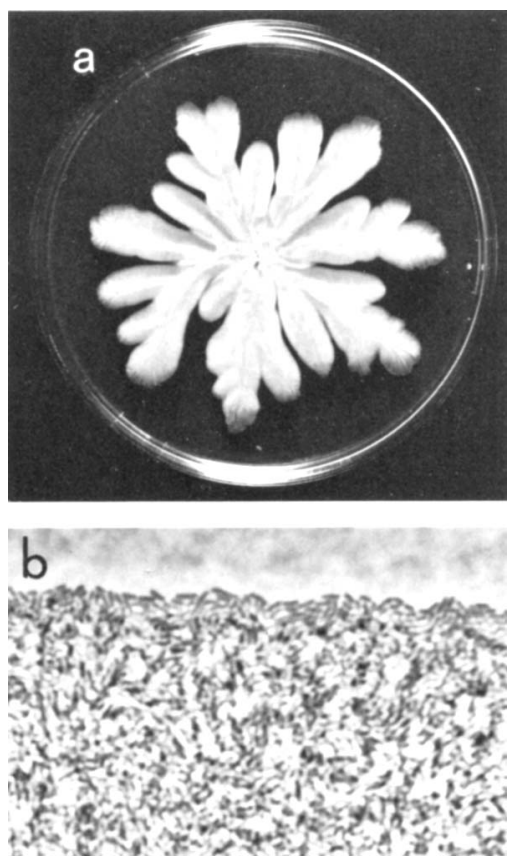

FIG. 5. (a) Spreading growth of $F$. indologenes GIFU 2007 on semisolid agar motility medium $(0.3 \%$ agar) after $20 \mathrm{~h}$ at $25^{\circ} \mathrm{C}$. (b) Phase-contrast micrograph of cells of $F$. indologenes GIFU 2007 in a monolayer at the edge of spreading growth on semisolid agar medium $\left(0.5 \%\right.$ agar) after $20 \mathrm{~h}$ at $25^{\circ} \mathrm{C} . \times 830$. 
TABLE 8. Variable characteristics among the 13 strains of $F$. indologenes

\begin{tabular}{|c|c|c|}
\hline \multirow{2}{*}{ Character } & \multicolumn{2}{|c|}{ Strain(s) producing the less common result } \\
\hline & Positive reaction & Negative reaction \\
\hline Growth on MacConkey agar & $\begin{array}{l}1389,1390,1393,1398,1399 \\
2007^{a}\end{array}$ & \\
\hline Fruity odor & $\begin{array}{l}1391,1393,1394,1396,1399 \\
2007\end{array}$ & \\
\hline Nitrate respiration & $1389,1390,1397,1399,2007$ & \\
\hline \multicolumn{3}{|l|}{ Acid from: } \\
\hline L-Arabinose & 1399,2007 & \\
\hline Ethanol $(3 \%)$ & $\begin{array}{l}1393,1394,1395,1396,1399 \\
2007\end{array}$ & \\
\hline Mannitol & $\begin{array}{l}1391,1393,1394,1396,1399 \\
2007\end{array}$ & \\
\hline Growth at $\mathrm{pH} 4.5$ & & $\begin{array}{l}1389,1391,1392,1394, \\
1397,2007\end{array}$ \\
\hline $\begin{array}{l}\text { Zinc dust test in negative } \mathrm{NO}_{2} \\
\text { test }\end{array}$ & & $\begin{array}{l}1389,1390,1397,1399, \\
2007\end{array}$ \\
\hline \multicolumn{3}{|l|}{ API ZYM tests } \\
\hline Esterase lipase (C8) & & $1390,1391,1392,1394$ \\
\hline Valine arylamidase & & $\begin{array}{l}1393,1395,1396,1397, \\
1398\end{array}$ \\
\hline$\beta$-Glucosidase & 2007 & \\
\hline$N$-Acetyl- $\beta$-D-glucosaminidase & $1347^{\mathrm{T}}$ & \\
\hline
\end{tabular}

${ }^{a}$ GIFU strain numbers (see Table 1 ).

gennaio to produce; N.L. adj. indologenes indole producing) cells are straight rods 0.5 by 1.3 to $2.5 \mu \mathrm{m}$ when the organism is grown on solid agar medium. In broth culture, many long, thread-like cells are present. Nonmotile and asporogenous. Colonies on heart infusion agar after $20 \mathrm{~h}$ of incubation at $30^{\circ} \mathrm{C}$ are $1 \mathrm{~mm}$ in diameter and have smooth surfaces and entire margins. Colonies of some strains become rhizoid within $20 \mathrm{~h}$. Colonies on any medium are deep orange due to intracellular pigments of the flexirubin type, which are present from the very beginning of the appearance of colonies. The visible absorption spectra of the orange pigments in acetone and in alkalinized acetone are shown in Fig. 3.

Growth on a plate of motility medium $(0.3 \%$ agar) spreads like a dahlia flower and almost covers the medium in a petri dish (diameter, 9 $\mathrm{cm}$ ) within $20 \mathrm{~h}$ at room temperature (Fig. 5a). The spreading growth on $0.5 \%$ agar medium in a petri dish is moderate, and almost no spreading occurs on $1 \%$ agar medium. The cells are arranged in a monolayer at the edge of the spreading growth on $0.5 \%$ agar medium (Fig. 5b). Young cultures of many strains have a strong fruity odor similar to that of $F$. odoratum.

Chemoorganotrophic. Luxurious growth is produced on ordinary peptone media, but no growth is produced in standard mineral base medium (12) supplemented with glucose and ammonium sulfate as the sole sources of carbon and nitrogen. Nearly $50 \%$ of the strains are inhibited on MacConkey agar (Nissui). Metabolism is respiratory and not fermentative. This organism can grow under anaerobic conditions in the presence of fumarate. Some strains reduce nitrate to nitrogen gas; other strains reduce neither nitrate nor nitrite. Catalase, indophenol oxidase, amylase, DNase, gelatinase, lipase, and tryptophanase are produced. On egg yolk agar a clear zone around colonies is produced within $20 \mathrm{~h}$; upon continued incubation this zone becomes increasingly turbid, and a grayish white halo is produced in the medium. Acid is produced oxidatively from fructose, glucose, glycogen, maltose, mannose, and trehalose, but not from $D$-arabinose, rhamnose, ribose, $x y l o s e$, galactose, cellobiose, lactose, melibiose, sucrose, raffinose, melezitose, adonitol, dulcitol, inulin, or salicin. Urease, acylamidase, phenylalanine deaminase, lysine decarboxylase, arginine dihydrolase, and ornithine decarboxylase are not produced. The major biochemical characteristics of $F$. indologenes, F. meningosepticum, and other organisms used in this study are summarized in Table 6. Selected characteristics that are useful for differentiating $F$. indologenes among the five Flavobacterium species are also shown in Table 6. Table 8 shows the variable characteristics among the 13 strains of $F$. indologenes studied.

Four major components of the cellular fatty acids of strain GIFU $1347^{\mathrm{T}}$ are $\mathrm{i}-\mathrm{C}_{15: 0}, \mathrm{i}-\mathrm{C}_{17: 1}$, i3-OH-C $17: 0$, and $\mathrm{i}-2-\mathrm{OH}-\mathrm{C}_{15: 0}$ (Table 4). The $\mathrm{G}+\mathrm{C}$ content of the DNA is $37.7 \mathrm{~mol} \%$. 
The type strain is ATCC 17898 (= CDC 3716 $=$ GIFU $1347=$ NCTC 10796).

Although this species as currently described represents a genetically rather heterogenous group of organisms, it is assigned a proper scientific name with a detailed description, both for convenience and to encourage further taxonomic research on the genus Flavobacterium.

\section{ACKNOWLEDGMENTS}

We are grateful to all who supplied valuable cultures. We thank S. Takaoka for phase-contrast micrographs and $\mathrm{H}$. Yabuuchi, Jr., for photographs of bacterial growth. We also thank Becton-Dickinson Oversea's Inc., Tokyo, Japan, for a supply of Sensi-Discs and Mueller-Hinton II agar plates.

Part of this work was supported by Grants-in-Aid for Developmental Scientific Research 387983 in 1978 and 487067 in 1979 from the Ministry of Education, Science and Culture, Japan.

\section{LITERATURE CITED}

1. Allen, R. L. J. 1940. The estimation of phosphorus. Biochem. J. 34:858-865.

2. Bauer, A. W., W. M. M. Kirby, J. C. Sherris, and M. Turck. 1966. Antibiotic susceptibility testing by a standardized single disk method. Am. J. Clin. Pathol. 45:493496.

3. Callies, E., and W. Mannheim. 1978. Classification of the Flavobacterium-Cytophaga complex on the basis of respiratory quinones and fumarate respiration. Int. J. Syst. Bacteriol. 28:14-19.

4. Callies, E., and W. Mannheim. 1980. Deoxyribonucleic acid relatedness of some menaquinone-producing Flavobacterium and Cytophaga strains. Antonie van Leeuwenhoek J. Microbiol. Serol. 46:41-49.

5. Christensen, P. J. 1977. The history, biology, and taxonomy of the Cytophaga group. Can. J. Microbiol. 23:15991653 .

6. Christensen, P. J., and F. D. Cook. 1972. The isolation and enumeration of cytophagas. Can. J. Microbiol. 18:1933-1940.

7. Folch, J., M. Lees, and G. H. S. Stanley. 1959. A simple method for the isolation and purification of total lipids from animal tissues. J. Biol. Chem. 226:497-509.

8. Harrison, F. C. 1929. The discoloration of halibut Can. J. Res. 1:214-239.

9. Henrichsen, J. 1972. Bacterial surface translocation: a survey and a classification. Bacteriol. Rev. 36:478-503.

10. Holmes, B., R. J. Owen, and D. G. Hollis. 1982. Flavobacterium spiritivorum, a new species isolated from human clinical specimens. Int. J. Syst. Bacteriol. 32:157-165.

11. Holmes, B., R. J. Owen, and R. E. Weaver. 1981. Flavobacterium multivorum, a new species isolated from human clinical specimens and previously known as group IIk, biotype 2. Int. J. Syst. Bacteriol. 31:21-34.

12. Hugh, R., and G. L. Gilardi. 1974. Pseudomonas, p. 250269. In E. H. Lennette, E. H. Spaulding, and J. P. Truant (ed.), Manual of clinical microbiology, 2nd ed. American Society for Microbiology, Washington, D.C.

13. Hugh, R., and G. L. Gilardi. 1980 . Pseudomonas, p. 288317. In E. H. Lennette, A. Balows, W. J. Hausler, Jr., and J. P. Truant (ed.), Manual of clinical microbiology, 3rd ed. American Society for Microbiology, Washington, D.C.

14. King, E. O. 1959. Studies on a group of previously unclassified bacteria associated with meningitis in infants. Am. J. Clin. Pathol. 31:241-247.

15. Leadbetter, E. R., and W. Godchaux III. 1981. Sulfonolipids novel in procaryotes are significant cellular components of many gliding bacteria, p. 135-143. In $\mathrm{H}$. Reichenbach and O. B. Weeks (ed.), The Flavobacterium-
Cytophaga group. GBF Monograph Series, no. 5. Verlag Chemie, Weinheim.

16. Marmur, J., and P. Doty. 1962. Determination of the base composition of deoxyribonucleic acid from its thermal denaturation temperature. J. Mol. Biol. 5:109-118.

17. McMeekin, T. A., and J. M. Shewan. 1978. Taxonomic strategies for Flavobacterium and related genera. J. Appl. Bacteriol. 45:321-332.

18. Mizuta, S., K. Imamura, N. Dateki, M. Suda, K. Kanetsugu, and K. Tasaki. 1974. Three cases of neonatal meningitis due to Flavobacterium meningosepticum. J. Pediatr. Pract. 37:1134-1140. (In Japanese.)

19. Moss, C. W., and S. B. Dees. 1978. Cellular fatty acids of Flavobacterium meningosepticum and Flavobacterium species group IIb. J. Clin. Microbiol. 8:772-774.

20. O'Donnell, A. G., J. R. Norris, R. C. W. Berkeley, D. Claus, T. Kaneko, N. A. Logan, and R. Nozaki. 1980. Characterization of Bacillus subtilis, Bacillus pumilis, Bacillus licheniformis, and Bacillus amyloliquefaciens by pyrolysis gas-liquid chromatography, deoxyribonucleic acid-deoxyribonucleic acid hybridization, biochemical test s, and API System. Int. J. Syst. Bacteriol. 30:448-459.

21. Owen, R. J., and B. Holmes. 1981. Identification and classification of Flavobacterium species from clinical sources, p. 39-50. In H. Reichenbach and O. B. Weeks (ed.), The Flavobacterium-Cytophaga group. GBF Monograph Series, no. 5. Verlag Chemie, Weinheim.

22. Owen, R. J., and S. P. Lapage. 1974. A comparison of strains of King's group IIb of Flavobacterium with Flavobacterium meningosepticum. Antonie van Leeuwenhoek J. Microbiol. Serol. 40:255-264.

23. Owen, R. J., and J. J. S. Snell. 1976. Deoxyribonucleic acid reassociation in the classification of flavobacteria. $J$. Gen. Microbiol. 93:89-102.

24. Perry, L. B. 1973 . Gliding motility in some nonspreading flexibacteria. J. Appl. Bacteriol. 36:227-232.

25. Price, K. W., and M. J. Pickett. 1981. Studies of clinical isolates of flavobacteria, p. 63-77. In H. Reichenbach and O. B. Weeks (ed.), The Flavobacterium-Cytophaga group. GBF Monograph Series, no. 5. Verlag Chemie, Weinheim.

26. Reichenbach, H., W. Kohl, and H. Achenbach. 1981. The flexirubin-type pigments, chemosystematically useful compounds, p. 101-108. In H. Reichenbach and O. B. Weeks (ed.), The Flavobacterium-Cytophaga group. GBF Monograph Series, no. 5. Verlag Chemie, Weinheim.

27. Tatum, H. W., W. H. Ewing, and R. E. Weaver. 1974. Miscellaneous gram-negative bacteria, p. 270-294. In E. H. Lennette, E. H. Spaulding, and J. P. Truant (ed.), Manual of clinical microbiology, 2nd ed. American Society for Microbiology, Washington, D.C.

28. Weaver, R. E., H. W. Tatum, and D. G. Hollis. 1972. The identification of unusual pathogenic gram-negative bacteria. Centers for Disease Control, Atlanta, Ga.

29. Webster, J. A., and R. Hugh. 1979. Flavobacterium aquatile and Flavobacterium meningosepticum: glucose nonfermenters with similar flagellar morphologies. Int. J. Syst. Bacteriol. 29:333-338.

30. Yabuuchi, E., and C. W. Moss. 1981. Cellular fatty acid composition of three species of Sphingobacterium gen. nov. and Cytophaga johnsonae. FEMS Microbiol. Lett. 13:87-91.

31. Yabuuchi, E., E. Tanimura, A. Ohyama, I. Yano, and A. Yamamoto. 1979. Flavobacterium devorans ATCC 10829: a strain of Pseudomonas paucimobilis. J. Gen. Appl. Microbiol. 25:95-107.

32. Yabuuchi, E., K. Yamanaka, and A. Ohyama. 1981. Evaluation of 36 Minitek tests and a new approach for identification of nonfermenters. J. Clin. Microbiol. 13:572-587.

33. Yabuuchi, E., I. Yano, S. Goto, E. Tanimura, T. Ito, and A. Ohyama. 1974. Description of Achromobacter xylosoxidans Yabuuchi and Ohyama 1971. Int. J. Syst. Bacteriol. 24:470-477.

34. Yabuuchi, E., I. Yano, T. Kaneko, and A. Ohyama. 1981. 
Classification of group IIK-2 and related bacteria, p. 7990. In H. Reichenbach and O. B. Weeks (ed.), The Flavobacterium-Cytophaga group. GBF Monograph Series, no. 5. Verlag Chemie, Weinheim.

35. Yano, I., Y. Ohno, M. Masui, K. Kato, E. Yabuuchi, and A. Ohyama. 1976. Occurrence of 2- and 3-hydroxy fatty acids in high concentrations in the extractable and bound lipids of Flavobacterium meningosepticum and Flavobacterium IIb. Lipids 11:685-688.

36. Yano, I., I. Tomiyasu, and E. Yabuuchi. 1982. Long-chain base composition of strains of three species of Sphingobacterium gen. nov. FEMS Microbiol. Lett. 15:303-307. 